\title{
Row Orientation and Canopy Position Affect Bud Differentiation, Leaf Area Index and Some Agronomical Traits of a Super High-Density Almond Orchard
}

\author{
Francesco Maldera ${ }^{1, *}$, Gaetano Alessandro Vivaldi ${ }^{1}$ (D), Ignasi Iglesias-Castellarnau ${ }^{2}$ and Salvatore Camposeo ${ }^{1, *(D)}$ \\ 1 Department of Agricultural and Environmental Science, University of Bari Aldo Moro, Via Amendola 165/A \\ 70126 Bari, Italy; gaetano.vivaldi@uniba.it \\ 2 Agromillora Catalana, Plaça Manuel Raventós 3-5, St. Sadurní d'Anoia, 08770 Barcelona, Spain; \\ iiglesias@agromillora.com \\ * Correspondence: francesco.maldera@uniba.it (F.M.); salvatore.camposeo@uniba.it (S.C.); \\ Tel./Fax: +39-080-5442982 (S.C.)
}

Citation: Maldera, F.; Vivaldi, G.A.; Iglesias-Castellarnau, I.; Camposeo, S. Row Orientation and Canopy Position Affect Bud Differentiation, Leaf Area Index and Some Agronomical Traits of a Super High-Density Almond Orchard. Agronomy 2021, 11, 251. https:// doi.org/10.3390/agronomy11020251

Academic Editor: Sara Serra Received: 31 December 2020 Accepted: 26 January 2021 Published: 29 January 2021

Publisher's Note: MDPI stays neutral with regard to jurisdictional claims in published maps and institutional affiliations.

Copyright: (c) 2021 by the authors. Licensee MDPI, Basel, Switzerland. This article is an open access article distributed under the terms and conditions of the Creative Commons Attribution (CC BY) license (https:// creativecommons.org/licenses/by/ $4.0 /)$.

\begin{abstract}
Super-high density (SHD) is the latest innovation in almond growing. This new cropping system needs to be studied in different climates, soils, latitudes and cultivars in order to promote more efficient and sustainable orchard management. This study shows the effects of two row orientations and different canopy positions on leaf area index (LAI), photosynthetically active radiation (PAR) and biological, phenological and agronomical parameters of a SHD almond orchard. Total bud number and flower bud number were higher for N-S row orientation and more wood buds were detected in top layers. LAI was strongly influenced by layer, but not by row orientation. Row orientation did not affect blooming or ripening phenology. Fruit number per layer was higher for North-South (N-S) row orientation and in middle layers; fruit set showed the opposite trend to flower bud and fruit numbers, achieving higher values for East-West (E-W) row orientation. Hulled fruit yield was not affected by row orientation but by canopy height. N-S oriented rows showed a greater number of empty nuts than E-W, but no differences were found between layers. We concluded that in SHD almond orchards, row orientation is determinant for sustainable crop management.
\end{abstract}

Keywords: cv Guara; available PAR; LAI; phenology; shelling; hull tight nuts; double seeds

\section{Introduction}

The almond tree (Prunus dulcis Mill. = Prunus amygdalus Batsch) produces a nut consumed all over the world: the area of almond trees harvested and production have increased constantly, reaching $+196 \%$ in 56 years [1]. Global almond market revenue was $\$ 10.5 \mathrm{~B}$ and global almond production 2.4 million tons in 2018 , up $3.8 \%$ from the previous year [2]. In the last 50 years, production has changed in terms of quantity and producing countries. In the 20th century the major almond producing countries were European countries, led by Italy and Spain [1]. After the 1980s there was an impressive fall in European production and an enormous rise in other countries, such as the United States of America, now the leader in global almond production, with trees mostly in the state of California [1]. In the 2000s, the European situation did not change at all. European production remained steady, while California's increased every year. In the 2010s, Spain and Portugal rapidly increased production on a large scale. Spain produced 320,000 tons in 2020 and expects to be the second largest world producer in 2025 with 625,700 tons, 143,000 tons of which from organic orchards. Today, there are about 120,000 ha of young orchards less than 4 years old [3]. Italy continues to convert its almond orchards to other crops [4]. The worst moment for Italian almond production was 2013, when production was 255,916 tons less than in $1961,-77.9 \%$ in 52 years, and 32,171 tons less than in 2000, $-30.7 \%$ in 13 years [1]. Since 2013, things have changed. Almond trees have regained 
importance through a campaign to promote Italian agricultural products and a rise in the price of almonds. The last 5 years showed a $+9.7 \%$ upturn in production [1].

Among the main factors responsible for this increase is a different mental approach to almond growing. Mechanization is the key to improving efficiency and productivity and the main guideline for modern agriculture. It can significantly reduce labour requirements, increasing efficiency and reducing production costs $[5,6]$. The traditional rainfed almond cropping system with few big trees per hectare, not amenable to mechanization, has been replaced by other more efficient and productive systems [7]. Modern almond orchards are medium to high density (300 and 500 trees per hectare), with vase training system, lower tree height, regular rectangular tree spacing layout, irrigation and mechanization [8].

The latest innovation in cropping systems was achieved by applying more than 20 years' experience with super high-density (SHD) olive orchards, adapting it to almond trees [9]. In olive growing, SHD cropping has already achieved high agronomic [10-14], economic [15] and environmental $[16,17]$ sustainability. The first SHD almond orchard was planted in 2010 near Lleida (Spain), and soon after, all almond producing countries start planting SHD orchards [18,19]. In 2020, world SHD almond orchards covered 5304 ha, mainly planted in Spain and Portugal. This new cropping system is also called 'Sustainable and Efficient System' or SES, due to optimized use of natural resources, such as soil and water, and agronomic inputs, such as fertilizer and chemical treatments, with respect to open-centre orchards $[20,21]$. The first SHD almond orchard in Italy was planted in 2013 near Andria (Apulia, southern Italy), and its example was followed by many Italian producers, reviving almond growing.

Orchard design has been studied to find the ideal solution for irradiance absorption [22,23]. Irradiance plays a key role in flower formation of perennial fruit crops, directly and indirectly affecting photosynthesis, carbohydrate availability and repartitioning. Each species responds to a different level of irradiance [24]. A big issue in the hedgerow fruit cropping system is row orientation, which affects the amount and direction of radiation reaching the trees.

The effects have been studied for hedgerow grapes and olive trees. The effect of row orientation on vegetative and reproductive growth characteristics of vineyards has been studied for a very long time [25] in relation to anthocyanin yield, skin-softening during maceration [26], grapevine susceptibility to different diseases due to lower or higher humidity in the canopy $[27,28]$ and production of certain important chemical compounds, directly responsible for yield and wine quality [29]. It has been confirmed that North-South $(\mathrm{N}-\mathrm{S})$ vs. East-West (E-W) row orientation has a strong influence on vineyards: the former is better for most major characteristics $[25,26,30]$.

Different studies of SHD olive orchards have also been conducted to determine whether differences in row orientation can affect vegetative growth and productivity. Vegetative growth and structure, floral development, fruit characteristics and oil productivity were analyzed [22-24,31-33]. For SHD olive orchards the results are controversial, but most recent research has shown that there are no significant differences between N-S and E-W row orientation [22,24,32].

Since introduction of the SHD system for almond trees is recent, there is only one published study assessing the biometric parameters of different cultivars [34]. Iglesias [21] studied the effect of spacing on yields by increasing light interception and irradiance absorption, and optimizing the inter-row spacing/edge height ratio to 1/1.1 under Spanish Mediterranean conditions. In North-South (N-S) oriented orchards, narrowing inter-row SHD distances (from 4.0 to 3.5 and $3.0 \mathrm{~m}$ for versions V1, V2 and V3, respectively) significantly increased yields by $31 \%$ and $65 \%$ with respect to the first version, V1. CasanovaGascon et al. [20] compared light interception in a SHD almond orchard and an open-centre system: the latter may have problems with "sink leaves" and fruit yield with respect to SHD. However, no studies have been published on the effect of different row orientations on vegetative and reproductive parameters in SHD almond systems. We therefore designed this study to provide insights into SHD almond cultivation techniques. 


\section{Materials and Methods}

\subsection{Site and Orchard}

This field study was carried in 2019 in an irrigated SHD almond orchard with a tree spacing of $3.8 \times 1.2 \mathrm{~m}\left(2190\right.$ trees ha $\left.{ }^{-1}\right)$. The cultivar was Guara (syn. Tuono [35,36]), an important self-compatible hard-shelled cultivar, planted in 2014 near Andria, southern Italy $\left(41^{\circ} 09^{\prime} 47^{\prime \prime} \mathrm{N}, 16^{\circ} 13^{\prime} 29^{\prime \prime}\right.$ E; altitude $\left.260 \mathrm{~m}\right)$. Rootpac-20 (Prunus pumila var. besseyi (Bailey) Gleason $\times$ Prunus cerasifera Ehrh.), a new size-controlling rootstock, was used. The climate of the region was typical Mediterranean, with an annual rainfall of $523 \mathrm{~mm}$ concentrated in autumn, winter and spring; the lowest monthly rainfall occurs in July $(22 \mathrm{~mm})$ and the highest in November $(61 \mathrm{~mm})$. Average annual temperature is $15.3^{\circ} \mathrm{C}$; the hottest month is August $\left(23.8^{\circ} \mathrm{C}\right)$ and the coldest January $\left(7.8^{\circ} \mathrm{C}\right)$. The soil is clay-loam, $40 \mathrm{~cm}$ deep. The orchards were managed using practices common in the area; drip lines were installed for controlled deficit irrigation, with a seasonal irrigation volume of $3000 \mathrm{~m}^{3} /$ ha. The plots were fertilized with $80 \mathrm{~kg} / \mathrm{ha} \mathrm{N}, 80 \mathrm{~kg} / \mathrm{ha} \mathrm{K}$ and $40 \mathrm{~kg} / \mathrm{ha}$ P. After the 2018 harvest and before that of 2019, the trees were mechanically topped at a height of $2.2 \mathrm{~m}$, hedged and trimmed. Two experimental plots, separated by approximately $20 \mathrm{~m}$, were established: one with rows extending North-South (N-S) and the other East-West (E-W). Each plot consisted of five rows in which the three central rows were the sampling area. Three blocks of five trees, randomly labelled, were identified in each row. The two hedgerow orientations had the same canopy dimensions: height $2.30 \mathrm{~m}$ and width $1.20 \mathrm{~m}$; the canopy started at $0.5 \mathrm{~m}$ above the soil surface.

\subsection{Definition of Canopy Position}

A total of 15 almond trees were chosen randomly in each experimental plot (N-S and E-W hedgerows) among the trees in the sampling area (the three central rows). The canopy of each tree was divided into three equal horizontal layers (layers $A, B$ and $C$, top, middle and bottom, $120-180 \mathrm{~cm}, 60-120 \mathrm{~cm}$ and $0-60 \mathrm{~cm}$ above the soil surface, respectively), and two sides.

\subsection{Bud Differentiation}

In winter, before budburst, six 1-year-old shoots per tree having a mean length of $30 \mathrm{~cm}$ were randomly selected and labelled, one for each layer on both sides of the hedge. On each shoot, total buds (TBs), wood buds (WBs) and flower buds (FBs) were counted. The number of flowers per shoot was recorded at full bloom (65 BBCH-Biologische Bundesanstalt, Bundessortenamt und CHemische Industrie-stage [37]).

\subsection{PAR and LAI}

Photosynthetically active radiation (PAR) and leaf area index (LAI) were measured with a PAR/LAI ceptometer (AccuPAR LP-80, METER Group Inc, Pullman, WA, USA.) for each layer and side, twice a month from foliation (end of March) to post-harvest (end of August). We chose 3 days of the year (DOYs) to plot the time trends: 110, 180 and 208 (20 April, 29 June and 27 July, respectively), representing stages 19 (leaves completely expanded), 77 (beginning of stone hardening) and 85 (hull completely split) of the $\mathrm{BBCH}$ scale, respectively [37].

\subsection{Phenology}

The flowering period and ripening times, corresponding to BBCH stages 65 and 85 , respectively [37], were recorded for all plots.

\subsection{Yield and Quality Parameters}

The number of fruits per shoot (FN) was counted and fruit set (FS) was calculated 30 days after full bloom (DOY 152, BBCH stage 71 [37]) with the expression FS (\%) = FN/FB.

At harvest time (BBCH stage 85 [37]), all the fruits in each layer and on each side were collected to measure fruit number per layer (FL) and hulled fruit yield (FY); polar gauge 
(PG) was measured on 10 hulled fruits per layer. Hulled fruit average weight (AW) was calculated by dividing FY by FL. On the same samples, shelling percentage (SP), hull-tight nuts (HT) and double seeds (DS) were measured.

\subsection{Data Analysis}

The field data were analyzed by one- and two-way analysis of variance (ANOVA) followed by post hoc testing (Student-Newman-Keuls protected test) using R 2.15.0 software (R Foundation for Statistical Computing, Free Software Foundation, Boston, MA, USA); standard error (SE) was also calculated. The data of the two hedgerow orientations underwent independent analysis of variance. Pearson correlation coefficients were evaluated.

\section{Results}

\subsection{Bud Differentiation}

Mean total buds (TBs) on shoots of E-W rows was 36.1, significantly lower than that of N-S rows (44.7), namely 19\% fewer buds (Table 1). Mean TBs on the east and west sides were significantly greater than on the north and south sides. The exposure with the highest mean TB (45.1), i.e., east, had $14 \%$ and $25 \%$ more buds than north (38.6) and south exposures (33.6), respectively. Significant differences were found in layer C, where $28 \%$ more buds were counted for N-S (43.8) than for E-W (31.4) row orientation. Significant differences in mean TBs were also found in layers B and C: the highest TB in layer B was recorded for eastern exposure (45.3), which was 25\% higher than mean TBs on the south side (34.2). The same was found for layer C, in which mean TBs was $40 \%$ higher on the eastern (45.3) than on the southern side (27.3). Finally, significant differences were found for southern exposure (27.3), where layer C had a mean TBs $44 \%$ and $25 \%$ lower than layers A (39.3) and B (34.2), respectively.

Table 1. Mean total number of buds per shoot (TB). The first letters denote significant differences between layers for a given exposure; the second letters denote significant differences between exposures for a given layer (SNK test). Lower case letters denote statistical differences with $p=0.05$. Capital letters denote statistical differences with $p=0.01$.

\begin{tabular}{ccccccc}
\hline Orientation & \multicolumn{3}{c}{ North-South } & \multicolumn{3}{c}{ East-West } \\
\hline Exposure & East & West & Mean & North & South & Mean \\
\hline Layer A $(120-180 \mathrm{~cm})$ & $44.6 \mathrm{~A}, \mathrm{~A}$ & $47.3 \mathrm{~A}, \mathrm{~A}$ & $45.9 \mathrm{~A}, \mathrm{~A}$ & $39.1 \mathrm{~A}, \mathrm{~A}$ & $39.3 \mathrm{~A}, \mathrm{~A}$ & $39.2 \mathrm{~A}, \mathrm{~A}$ \\
Layer B $(60-120 \mathrm{~cm})$ & $45.3 \mathrm{~A}, \mathrm{a}$ & $43.4 \mathrm{~A}, \mathrm{a}$ & $44.4 \mathrm{~A}, \mathrm{~A}$ & $41.1 \mathrm{~A}, \mathrm{a}$ & $34.2 \mathrm{~A}, \mathrm{ab}$ & $37.7 \mathrm{~A}, \mathrm{~A}$ \\
Layer C $(0-60 \mathrm{~cm})$ & $45.3 \mathrm{~A}, \mathrm{a}$ & $42.4 \mathrm{~A}, \mathrm{a}$ & $43.8 \mathrm{~A}, \mathrm{~A}$ & $35.6 \mathrm{~A}, \mathrm{a}$ & $27.3 \mathrm{~B}, \mathrm{~b}$ & $31.4 \mathrm{~A}, \mathrm{~B}$ \\
\hline Mean & $45.1 \mathrm{~A}$ & $44.4 \mathrm{~A}$ & $44.7 \mathrm{~A}$ & $38.6 \mathrm{~B}$ & $33.6 \mathrm{~B}$ & $36.1 \mathrm{~B}$ \\
\hline
\end{tabular}

Significant differences in mean number of wood buds per shoot (WBs) were found between orientations, E-W orientation (30.4) having 23\% more wood buds than N-S (23.5) (Table 2). Significant differences in total WBs were found in relation to layer. Layer A (32.7) had 15\% and 37\% more wood buds than layers B (27.7) and C (20.6), respectively. Significant differences in mean WBs were also found in relation to exposure. Mean WBs (32.1) on the north side was 10\%, 23\% and 30\% higher than on the south (28.7), west (24.6) and east (22.5) sides. Significant differences in mean WBs were also found in relation to orientation and layer. In layer B, mean WBs were significantly higher for E-W (32.3) than for N-S orientation (23.0). In layer C, mean WBs were significantly higher for E-W (24.6) than for N-S orientation (16.5). For N-S orientation, layer A (31.1) had 26\% more buds than layer B (23.0) and 47\% more buds than C (16.5). For E-W orientation, layers A and B had equal mean WBs, which were significantly higher than that of layer C. A $28 \%$ decrement in mean WBs was recorded between layers A (34.3) and C (24.6). Comparing exposures, mean WBs were significantly higher in layer B on the north side than on the other sides, having $18 \%, 30 \%$ and $40 \%$ more WBs than the south (29.2), west (24.7) and east (21.3) sides, respectively. Likewise in layer C, mean WBs (25.3) were 5\%, 34\% and 35\% higher 
(significant) higher on the north than on the south (23.9), west (16.7) and east (16.4) sides, respectively. Significant differences in mean WBs were found between layers with eastern exposure. Mean WBs in layer A (29.8) were 28\% and 44\% higher than in layers B (21.3) and C (16.4), respectively. For western exposure, mean WBs in layer A (32.4) were $24 \%$ and $48 \%$ higher than in layers B (24.7) and C (16.7), respectively. For northern exposure, mean WBs in layers A and B (35.5) were 29\% higher than in layer C (25.3). For southern exposure, mean WBs in layers A and B (31.1) were 23\% higher than in layer C (23.9).

Table 2. Mean number of wood buds per shoot (WB). The first letters denote significant differences between layers for a given exposure; the second letters denote significant differences between exposures for a given layer (SNK test). Lower case letters denote statistical differences with $p=0.05$. Capital letters denote statistical differences with $p=0.01$.

\begin{tabular}{ccccccc}
\hline Orientation & \multicolumn{3}{c}{ North-South } & \multicolumn{3}{c}{ East-West } \\
\hline Exposure & East & West & Mean & North & South & Mean \\
\hline Layer A $(120-180 \mathrm{~cm})$ & $29.8 \mathrm{a}, \mathrm{A}$ & $32.4 \mathrm{a}, \mathrm{A}$ & $31.1 \mathrm{~A}, \mathrm{~A}$ & $35.5 \mathrm{a}, \mathrm{A}$ & $33.0 \mathrm{a}, \mathrm{A}$ & $34.3 \mathrm{~A}, \mathrm{~A}$ \\
Layer B $(60-120 \mathrm{~cm})$ & $21.3 \mathrm{~b}, \mathrm{~B}$ & $24.7 \mathrm{ab}, \mathrm{ab}$ & $23.0 \mathrm{~B}, \mathrm{~B}$ & $35.5 \mathrm{a}, \mathrm{a}$ & $29.2 \mathrm{a}, \mathrm{ab}$ & $32.3 \mathrm{~A}, \mathrm{~A}$ \\
Layer C $(0-60 \mathrm{~cm})$ & $16.4 \mathrm{~b}, \mathrm{~b}$ & $16.7 \mathrm{~b}, \mathrm{~b}$ & $16.5 \mathrm{C}, \mathrm{B}$ & $25.3 \mathrm{~b}, \mathrm{a}$ & $23.9 \mathrm{~b}, \mathrm{ab}$ & $24.6 \mathrm{~B}, \mathrm{~A}$ \\
\hline Mean & $22.5 \mathrm{~B}$ & $24.6 \mathrm{~B}$ & $23.5 \mathrm{~B}$ & $32.1 \mathrm{~A}$ & $28.7 \mathrm{~A}$ & $30.4 \mathrm{~A}$ \\
\hline
\end{tabular}

Significant differences in mean number of flower buds per shoot (FBs) were found between E-W and N-S orientations (Table 3). N-S orientation (23.3) produced 70\% more flower buds than E-W (7.0). Significant differences were also found between exposures, in which mean FBs (24.9) were 69\% and 74\% higher for eastern than for northern (7.6) and southern (6.4) exposures, respectively. Substantial differences in mean FBs were found between orientations in every layer. Layer A with N-S orientation had $56 \%$ more flower buds (16.3) than with E-W orientation (7.2). Layer B with N-S orientation had more than three times more FBs (23.7) than with E-W orientation (7.4). Layer C with N-S orientation had almost five times more FBs (29.7) than with E-W orientation (6.4). In the N-S oriented orchard, mean FBs in layer C (29.7) were 20\% and 45\% higher (significant) than mean FBs in layers B (23.7) and A (16.3).

Table 3. Mean number of flower buds per shoot (FB). The first letters denote significant differences between layers for a given exposure; the second letters denote significant differences between exposures for a given layer (SNK test). Lower case letters denote statistical differences with $p=0.05$. Capital letters denote statistical differences with $p=0.01$.

\begin{tabular}{ccccccc}
\hline Orientation & \multicolumn{3}{c}{ North-South } & \multicolumn{3}{c}{ East-West } \\
\hline Exposure & East & West & Mean & North & South & Mean \\
\hline Layer A $(120-180 \mathrm{~cm})$ & $16.1 \mathrm{~b}, \mathrm{ab}$ & $16.6 \mathrm{~b}, \mathrm{a}$ & $16.3 \mathrm{~B}, \mathrm{~A}$ & $5.3 \mathrm{~b}, \mathrm{~b}$ & $9.4 \mathrm{a}, \mathrm{ab}$ & $7.2 \mathrm{~A}, \mathrm{~B}$ \\
Layer B $(60-120 \mathrm{~cm})$ & $27.0 \mathrm{ab}, \mathrm{A}$ & $20.5 \mathrm{ab}, \mathrm{A}$ & $23.7 \mathrm{AB}, \mathrm{A}$ & $6.7 \mathrm{ab}, \mathrm{B}$ & $6.1 \mathrm{ab}, \mathrm{B}$ & $7.4 \mathrm{~A}, \mathrm{~B}$ \\
Layer C $(0-60 \mathrm{~cm})$ & $31.5 \mathrm{a}, \mathrm{A}$ & $27.8 \mathrm{a}, \mathrm{A}$ & $29.7 \mathrm{~A}, \mathrm{~A}$ & $10.7 \mathrm{a}, \mathrm{B}$ & $3.8 \mathrm{~b}, \mathrm{~B}$ & $6.4 \mathrm{~A}, \mathrm{~B}$ \\
\hline Mean & $24.9 \mathrm{~A}$ & $21.6 \mathrm{~A}$ & $23.3 \mathrm{~A}$ & $7.6 \mathrm{~B}$ & $6.4 \mathrm{~B}$ & $7.0 \mathrm{~B}$ \\
\hline
\end{tabular}

Significant differences in mean number of flower buds per shoot (FBs) were found between exposures in every layer. In layer A, western exposure produced mean FBs (16.6) that were 3\%, 44\% and 68\% higher (significant) than east (16.1), south (9.4) and north (5.3) exposures, respectively. In layer $B$, the west and east sides produced equal FBs, but mean FBs of the eastern side (27.0) were $75 \%$ and $77 \%$ higher than on the north (6.7) and south (6.1) sides, respectively. In layer C, mean FBs were equal on the west and east sides, but mean FBs on the eastern side (31.5) were $65 \%$ and $88 \%$ higher than on the north (10.7) and south (3.8) sides. Finally, on the eastern side, significant differences were found between layers: layer C (31.5) produced $14 \%$ and $49 \%$ more flower buds than layers B (27.0) and A (16.1). On the western side, layer C (27.8) produced $26 \%$ and $40 \%$ more FBs than layers B 
(20.5) and $A$ (16.6). The same trend was found on the northern side, with layer $C$ producing a mean FBs (10.7) that was $37 \%$ and $50 \%$ greater than those produced by layers $B(6.7)$ and A (5.3), respectively. On the southern side, layer A (9.4) produced $35 \%$ and $60 \%$ more flower buds than layer B (6.1) and C (3.8), respectively. It was also observed that E and W exposures (N-S row orientation) led to almost equal numbers of flower and wood buds, whereas $\mathrm{N}$ and $\mathrm{S}$ exposures (E-W row orientation) led to flower buds that were only $20 \%$ of the total (Figure 1).

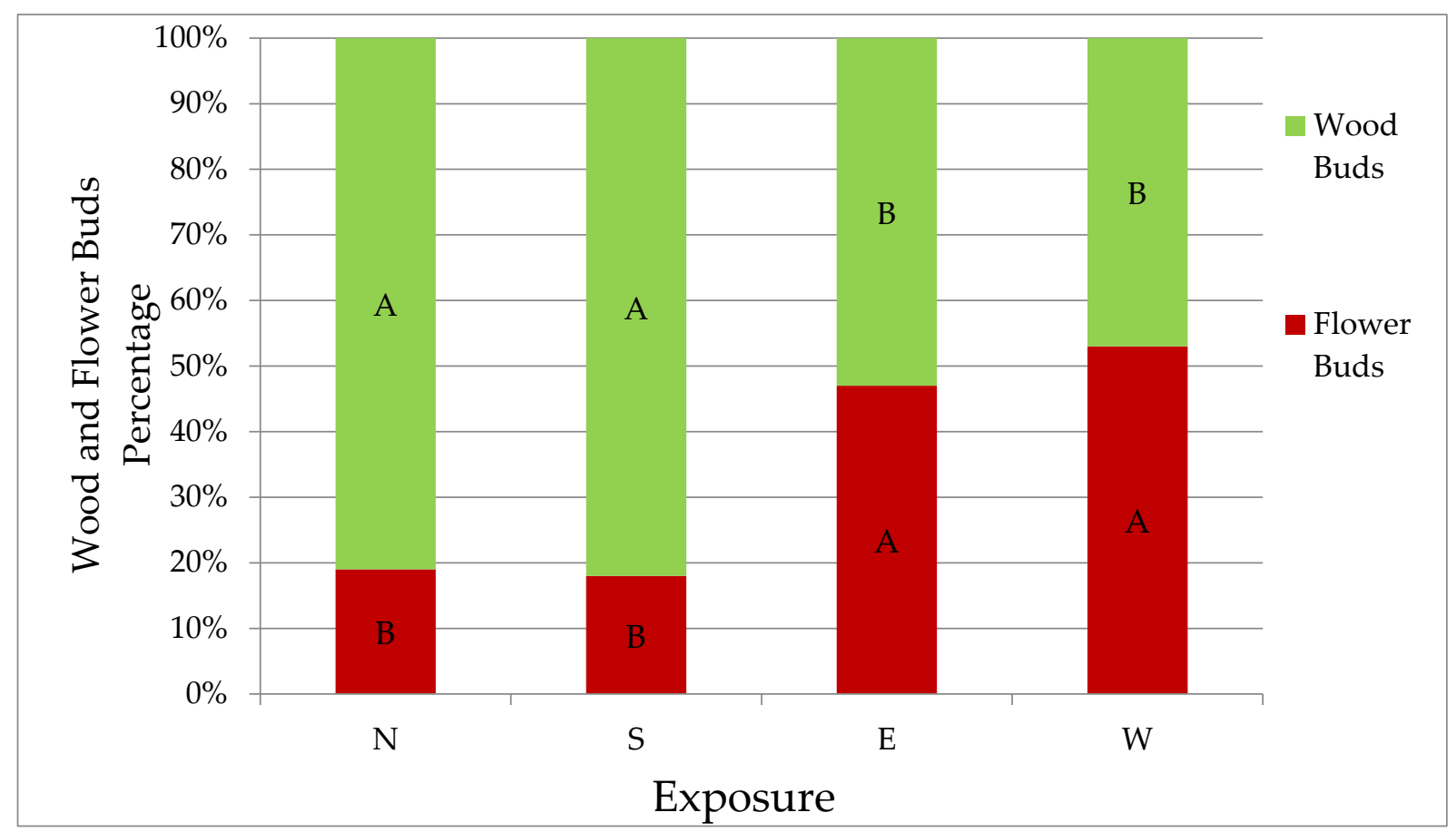

Figure 1. Wood and flower buds percentage per shoot for a given exposure (North, South, East, West). The $100 \%$ represents the total buds number per shoot. The letters denote significant differences among exposures $(p=0.01$; SNK test).

\subsection{LAI and PAR}

Table 4 shows the seasonal pattern of LAI in the period March-August. At DOY 82 foliation was only partial (15 BBCH), leading to the lowest LAI for all layers and both orientations. LAI increased steeply to DOY $152(71 \mathrm{BBCH}$, fruit set), then levelled off to its maximum at DOY $180(77 \mathrm{BBCH}, 70 \%$ fruit final size). At DOY $194(79 \mathrm{BBCH}, 70 \%$ final size) and 208 (85 BBCH, hull split completed) LAI was slightly lower than at DOY 180, whereas at DOY 237 (92 BBCH, leaf senescence) there was a significant $40 \%$ decrease in LAI, also due to harvesting, which occurred at DOY 208 [34].

Table 4. LAI $\left(\mathrm{m}^{2} \mathrm{~m}^{-2}\right.$ ) seasonal pattern recorded in different layers (layer A 120-180 cm, layer B 60-120 cm, layer C 0-60 cm) for two row orientations. The letter denotes statistical differences between DOYs for each layer (SNK test). Lower case letters denote statistical differences with $p=0.05$. Capital letters denote statistical differences with $p=0.01$.

\begin{tabular}{|c|c|c|c|c|c|c|c|c|c|c|c|c|}
\hline \multicolumn{13}{|c|}{ Orientation North-South } \\
\hline \multicolumn{13}{|c|}{ DOY } \\
\hline & 82 & 96 & 110 & 127 & 139 & 152 & 167 & 180 & 194 & 208 & 237 & Mean \\
\hline $\begin{array}{c}\text { Layer A } \\
(120-180 \mathrm{~cm})\end{array}$ & $0.79 \mathrm{D}$ & $0.97 \mathrm{D}$ & $1.38 \mathrm{C}$ & $1.58 \mathrm{BC}$ & $1.63 \mathrm{BC}$ & $1.69 \mathrm{AC}$ & $1.85 \mathrm{AB}$ & $1.95 \mathrm{~A}$ & $1.47 \mathrm{C}$ & $1.37 \mathrm{C}$ & $0.81 \mathrm{D}$ & 1.40 \\
\hline $\begin{array}{c}\text { Layer B } \\
(60-120 \mathrm{~cm})\end{array}$ & $1.17 \mathrm{E}$ & $1.54 \mathrm{D}$ & $1.93 \mathrm{C}$ & $2.03 \mathrm{BC}$ & $2.22 \mathrm{BC}$ & $2.30 \mathrm{BC}$ & $2.44 \mathrm{AB}$ & $2.69 \mathrm{~A}$ & $2.10 \mathrm{BC}$ & $2.09 \mathrm{BC}$ & $1.13 \mathrm{E}$ & 1.97 \\
\hline $\begin{array}{l}\text { Layer C } \\
(0-60 \mathrm{~cm})\end{array}$ & $1.70 \mathrm{G}$ & $2.07 \mathrm{~F}$ & $2.64 \mathrm{E}$ & $2.94 \mathrm{DE}$ & $3.14 \mathrm{CD}$ & $3.30 \mathrm{BC}$ & $3.59 \mathrm{AB}$ & $3.78 \mathrm{~A}$ & $2.93 \mathrm{ED}$ & $2.65 \mathrm{E}$ & $1.53 \mathrm{G}$ & 2.75 \\
\hline Mean & $1.22 \mathrm{~F}$ & $1.53 \mathrm{E}$ & $1.98 \mathrm{D}$ & $2.18 \mathrm{CD}$ & $2.33 \mathrm{BD}$ & $2.43 \mathrm{BC}$ & $2.63 \mathrm{AB}$ & $2.81 \mathrm{~A}$ & $2.17 \mathrm{CD}$ & $2.04 \mathrm{D}$ & $1.16 \mathrm{~F}$ & 2.04 \\
\hline
\end{tabular}


Table 4. Cont.

\begin{tabular}{|c|c|c|c|c|c|c|c|c|c|c|c|c|}
\hline \multicolumn{13}{|c|}{ Orientation East-West } \\
\hline \multicolumn{13}{|c|}{ DOY } \\
\hline & 82 & 96 & 110 & 127 & 139 & 152 & 167 & 180 & 194 & 208 & 237 & Mean \\
\hline $\begin{array}{c}\text { Layer A } \\
(120-180 \mathrm{~cm})\end{array}$ & $1.00 \mathrm{E}$ & $1.18 \mathrm{DE}$ & $1.47 \mathrm{CD}$ & $1.67 \mathrm{BC}$ & $1.87 \mathrm{AB}$ & $2.01 \mathrm{AB}$ & $2.14 \mathrm{~A}$ & $2.23 \mathrm{~A}$ & $2.00 \mathrm{AB}$ & $1.86 \mathrm{AB}$ & $1.32 \mathrm{CE}$ & 1.70 \\
\hline $\begin{array}{c}\text { Layer B } \\
(60-120 \mathrm{~cm})\end{array}$ & $1.31 \mathrm{D}$ & $1.49 \mathrm{D}$ & $2.03 \mathrm{C}$ & $2.26 \mathrm{BC}$ & $2.30 \mathrm{BC}$ & $2.58 \mathrm{AB}$ & $2.67 \mathrm{AB}$ & $2.99 \mathrm{~A}$ & $2.62 \mathrm{AB}$ & $2.50 \mathrm{AB}$ & $1.57 \mathrm{D}$ & 2.21 \\
\hline $\begin{array}{l}\text { Layer C } \\
(0-60 \mathrm{~cm})\end{array}$ & $1.59 \mathrm{D}$ & $2.04 \mathrm{D}$ & $2.85 \mathrm{C}$ & $3.13 \mathrm{BC}$ & $3.27 \mathrm{BC}$ & $3.52 \mathrm{AB}$ & $3.84 \mathrm{~A}$ & $3.92 \mathrm{~A}$ & $3.58 \mathrm{AB}$ & $3.17 \mathrm{BC}$ & $1.81 \mathrm{D}$ & 2.97 \\
\hline Mean & $1.30 \mathrm{D}$ & $1.57 \mathrm{D}$ & $2.11 \mathrm{C}$ & $2.35 \mathrm{BC}$ & $2.48 \mathrm{~B}$ & $2.70 \mathrm{AB}$ & $2.88 \mathrm{~A}$ & $3.05 \mathrm{~A}$ & $2.73 \mathrm{AB}$ & $2.51 \mathrm{~B}$ & $1.57 \mathrm{D}$ & 2.29 \\
\hline
\end{tabular}

At DOY 180, when LAI was maximum, it was $28 \%$ and $45 \%$ higher in layer C $\left(3.8 \mathrm{~m}^{2} / \mathrm{m}^{2}\right)$ than in layers B $\left(2.9 \mathrm{~m}^{2} / \mathrm{m}^{2}\right)$ and A $\left(2.1 \mathrm{~m}^{2} / \mathrm{m}^{2}\right)$ (Table 5$)$. For N-S orientation, mean LAI $\left(3.8 \mathrm{~m}^{2} / \mathrm{m}^{2}\right)$ in layer C was $29 \%$ and $47 \%$ higher than in layers B (2.7) and A (2.0). For E-W orientation, mean LAI $\left(3.9 \mathrm{~m}^{2} / \mathrm{m}^{2}\right)$ in layer $C$ was always the highest, $23 \%$ and $44 \%$ higher than in layers B (3.0) and A (2.2). The same situation was found for the different exposures: mean LAI in layer $C$ was always the highest (4.0, 3.6, 3.8 and $4.0 \mathrm{~m}^{2} / \mathrm{m}^{2}$ for east, west, north and south exposure, respectively) and that in layer A was the lowest $\left(2.0,1.9,2.3\right.$ and $2.2 \mathrm{~m}^{2} / \mathrm{m}^{2}$, respectively).

Table 5. Mean LAI $\left(\mathrm{m}^{2} \mathrm{~m}^{-2}\right)$ at DOY 180. The first letters denote significant differences between layers for a given exposure; the second letters denote significant differences between exposures for a given layer (SNK test). Lower case letters denote statistical differences with $p=0.05$. Capital letters denote statistical differences with $p=0.01$.

\begin{tabular}{ccccccc}
\hline Orientation & \multicolumn{3}{c}{ North-South } & \multicolumn{3}{c}{ East-West } \\
\hline Exposure & East & West & Mean & North & South & Mean \\
\hline Layer A $(120-180 \mathrm{~cm})$ & $2.0 \mathrm{C}, \mathrm{A}$ & $1.9 \mathrm{C}, \mathrm{A}$ & $2.0 \mathrm{C}, \mathrm{A}$ & $2.3 \mathrm{~B}, \mathrm{~A}$ & $2.2 \mathrm{C}, \mathrm{A}$ & $2.2 \mathrm{C}, \mathrm{A}$ \\
Layer B $(60-120 \mathrm{~cm})$ & $2.9 \mathrm{~B}, \mathrm{~A}$ & $2.5 \mathrm{~B}, \mathrm{~A}$ & $2.7 \mathrm{~B}, \mathrm{~A}$ & $3.0 \mathrm{~b}, \mathrm{~A}$ & $3.0 \mathrm{~B}, \mathrm{~A}$ & $3.0 \mathrm{~B}, \mathrm{~A}$ \\
Layer C $(0-60 \mathrm{~cm})$ & $4.0 \mathrm{~A}, \mathrm{~A}$ & $3.6 \mathrm{~A}, \mathrm{~A}$ & $3.8 \mathrm{~A}, \mathrm{~A}$ & $3.8 \mathrm{a}, \mathrm{A}$ & $4.0 \mathrm{~A}, \mathrm{~A}$ & $3.9 \mathrm{~A}, \mathrm{~A}$ \\
\hline Mean & $2.9 \mathrm{~A}$ & $2.7 \mathrm{~A}$ & $2.8 \mathrm{~A}$ & $3.0 \mathrm{~A}$ & $3.0 \mathrm{~A}$ & $3.1 \mathrm{~A}$ \\
\hline
\end{tabular}

Photosynthetically active radiation, PAR, in the tree canopy decreased significantly from layer A to layer $C$ for all exposures (Table 6). In fact, mean PAR in the top layer was at least $18 \%$ and $52 \%$ higher on the west and north sides, respectively, than in the middle and lower layers. Although PAR below mean values was not influenced by exposures, significant differences were recorded in every layer. In the top layer, mean PAR on the west and east sides (957.4 and $944.9 \mu \mathrm{mol}$ photons $\mathrm{m}^{-2} \mathrm{~s}^{-1}$, respectively) was highest, whereas on the north side it was the lowest (759.3). Mean PAR on the south side stood in the middle $\left(869.9 \mu \mathrm{mol}\right.$ photons $\left.\mathrm{m}^{-2} \mathrm{~s}^{-1}\right)$. In layer $\mathrm{B}$, mean PAR was highest on the west side (787.7), and lowest on the north side (583.0). Mean PAR on the east and south sides was intermediate between values on the west and north sides, the former being higher than the latter (657.7 and 618.9, respectively). In layer C, mean PAR was higher on the west side (411.5), and lower on the east side (298.6). Mean PAR was quite similar on the north and south sides (367.6 and 349.3, respectively). 
Table 6. Mean PAR ( $\mu \mathrm{mol}$ photons $\mathrm{m}^{-2} \mathrm{~s}^{-1}$ ) in the canopy. The first letters denote significant differences between layers for a given exposure; the second letters denote significant differences between exposures for a given layer (SNK test). Lower case letters denote statistical differences with $p=0.05$. Capital letters denote statistical differences with $p=0.01$.

\begin{tabular}{ccccccc}
\hline Orientation & \multicolumn{3}{c}{ North-South } \\
\hline Exposure & East & West & Mean & North & South & Mean \\
\hline Layer A $(120-180 \mathrm{~cm})$ & $944.9 \mathrm{~A}, \mathrm{~A}$ & $957.4 \mathrm{~A}, \mathrm{~A}$ & $951.2 \mathrm{~A}, \mathrm{~A}$ & $759.3 \mathrm{~A}, \mathrm{C}$ & $869.9 \mathrm{~A}, \mathrm{~B}$ & $814.6 \mathrm{~A}, \mathrm{~B}$ \\
Layer B $(60-120 \mathrm{~cm})$ & $657.7 \mathrm{~B}, \mathrm{~B}$ & $787.7 \mathrm{~B}, \mathrm{~A}$ & $722.7 \mathrm{~B}, \mathrm{~A}$ & $583.0 \mathrm{~B}, \mathrm{C}$ & $618.9 \mathrm{~B}, \mathrm{BC}$ & $601.0 \mathrm{~B}, \mathrm{~B}$ \\
Layer C $(0-60 \mathrm{~cm})$ & $298.6 \mathrm{C}, \mathrm{C}$ & $411.5 \mathrm{C}, \mathrm{A}$ & $355.1 \mathrm{C}, \mathrm{A}$ & $367.6 \mathrm{C}, \mathrm{B}$ & $349.3 \mathrm{C}, \mathrm{B}$ & $363.0 \mathrm{C}, \mathrm{A}$ \\
\hline Mean & $633.7 \mathrm{~A}$ & $718.9 \mathrm{~A}$ & $676.3 \mathrm{~A}$ & $570.0 \mathrm{~A}$ & $612.7 \mathrm{~A}$ & $591.4 \mathrm{~A}$ \\
\hline
\end{tabular}

Regarding PAR in relation to DOY and layer, in the orchard with N-S orientation, there was a significant difference in PAR between the three layers on the eastern side at DOY 110 and 180: PAR in the top layer was 51\% and 30\% higher than in the middle layer, and $65 \%$ and $68 \%$ higher than in the bottom layer, respectively (Figure 2). At DOY 208, PAR was highest in the top layer, and similar in the middle and bottom layers. On the W side, PAR in the top layer was significantly higher in the top layer at DOYs 110 and 208 than in the other two layers, which showed similar values. At DOY 180, PAR showed a significant difference between the top and bottom layers and between the middle and bottom layers, while PAR in the top and middle layers was substantially the same. No significant differences in PAR were found in relation to exposure for a given layer and DOY, except at DOY 110, when borderline significant differences in PAR were found between the middle and bottom layers.

EAST

WEST

Layer A (120-180 cm)
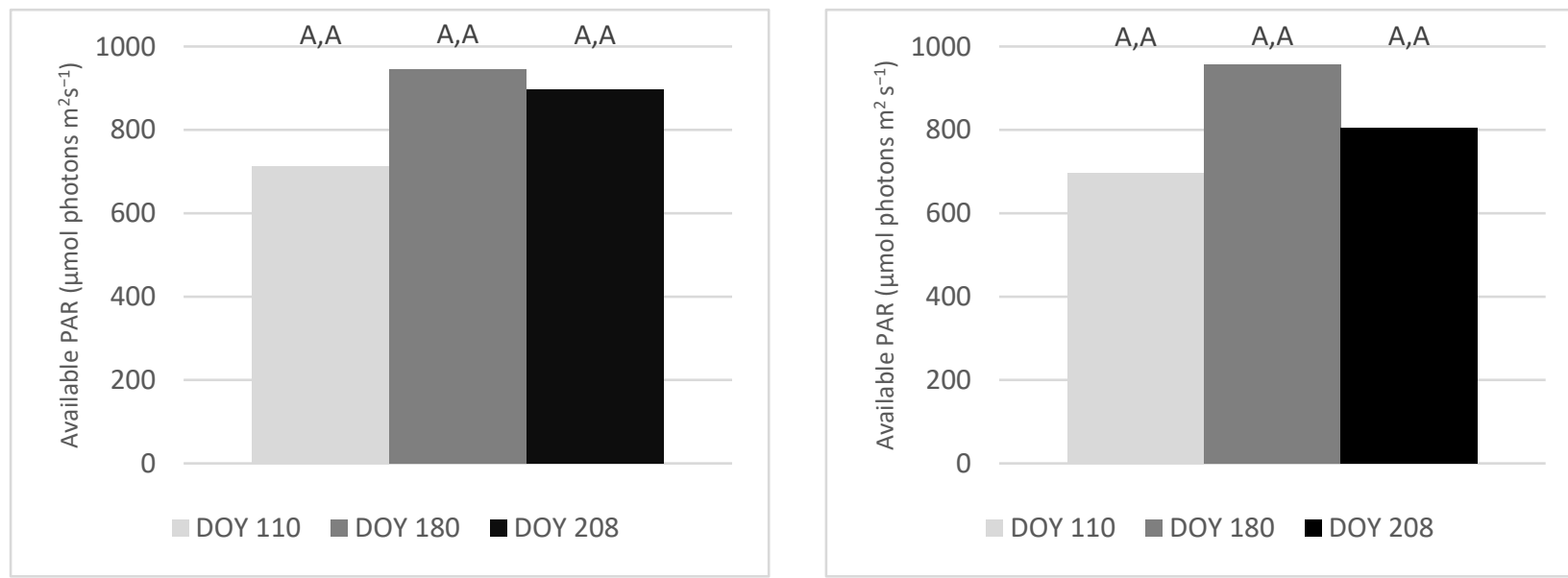

Figure 2. Cont. 
Layer B $(60-120 \mathrm{~cm})$
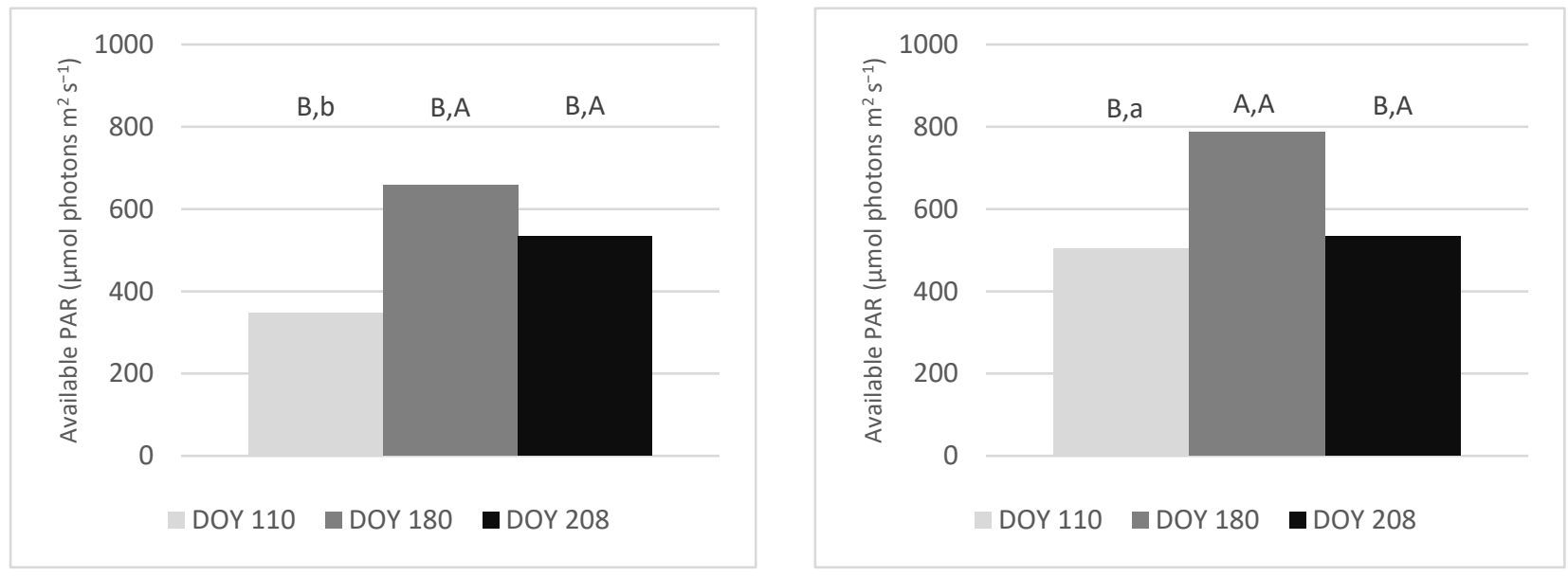

Layer C $(0-60 \mathrm{~cm})$
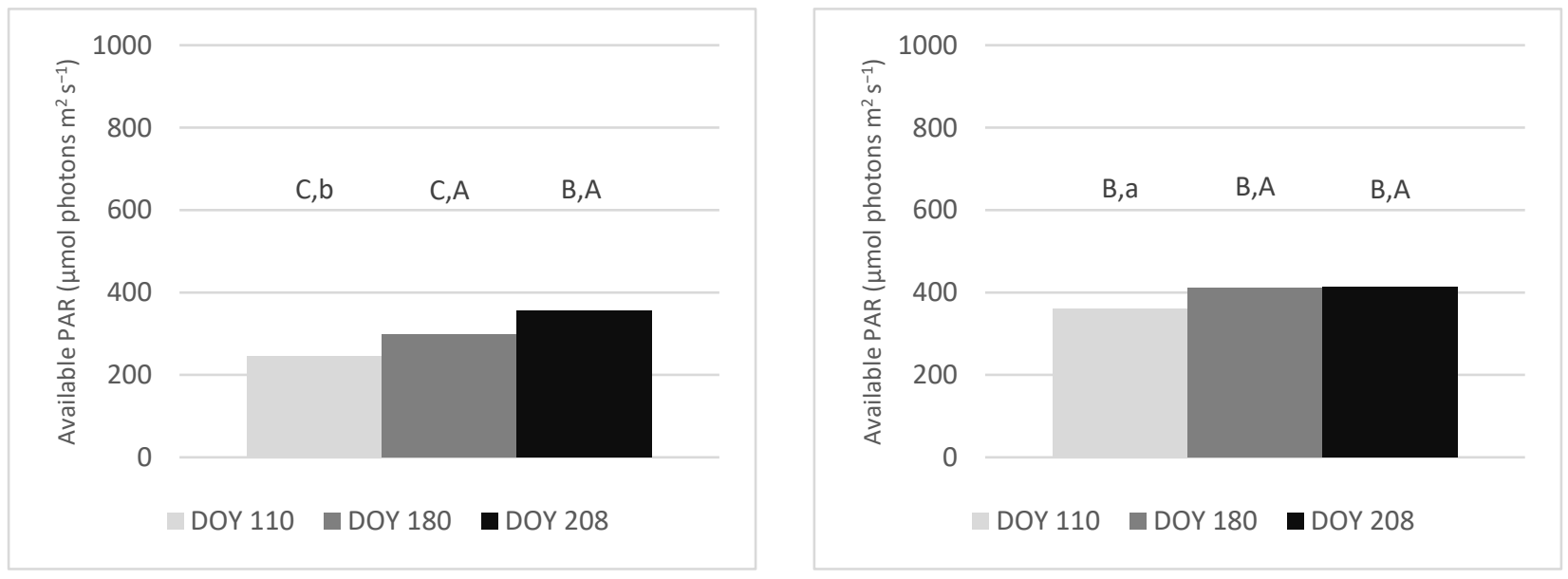

Figure 2. Available PAR ( $\mu \mathrm{mol}$ photons $\mathrm{m}^{2} \mathrm{~s}^{-1}$ ) in relation to layer (layers A, B and C) on east and west sides of orchard with north-south orientation on three DOYs. The first letter denotes significant differences between layers for a given exposure and DOY $(n=45 ; p=0.05 / 0.01$; SNK test); the second letter denotes significant differences between exposure for a given layer and DOY $(n=90 ; p=0.05 / 0.01$; SNK test). Lower case letters denote statistical differences with $p=0.05$. Capital letters denote statistical differences with $p=0.01$.

In the orchard with E-W orientation, PAR on the $\mathrm{N}$ side on DOYs 110 and 180 was significantly higher in the top and middle than in the bottom layer, whereas at DOY 208, PAR was highest in the top layer and was similar in the middle and bottom layers (Figure 3). On the $S$ side, PAR showed significant differences in relation to layer and DOY, being highest in the top layer and lowest in bottom layer. Borderline significant differences in PAR in relation to exposure were only recorded in the bottom layer at DOY 110. 
NORTH

SOUTH

Layer A (120-180 cm)
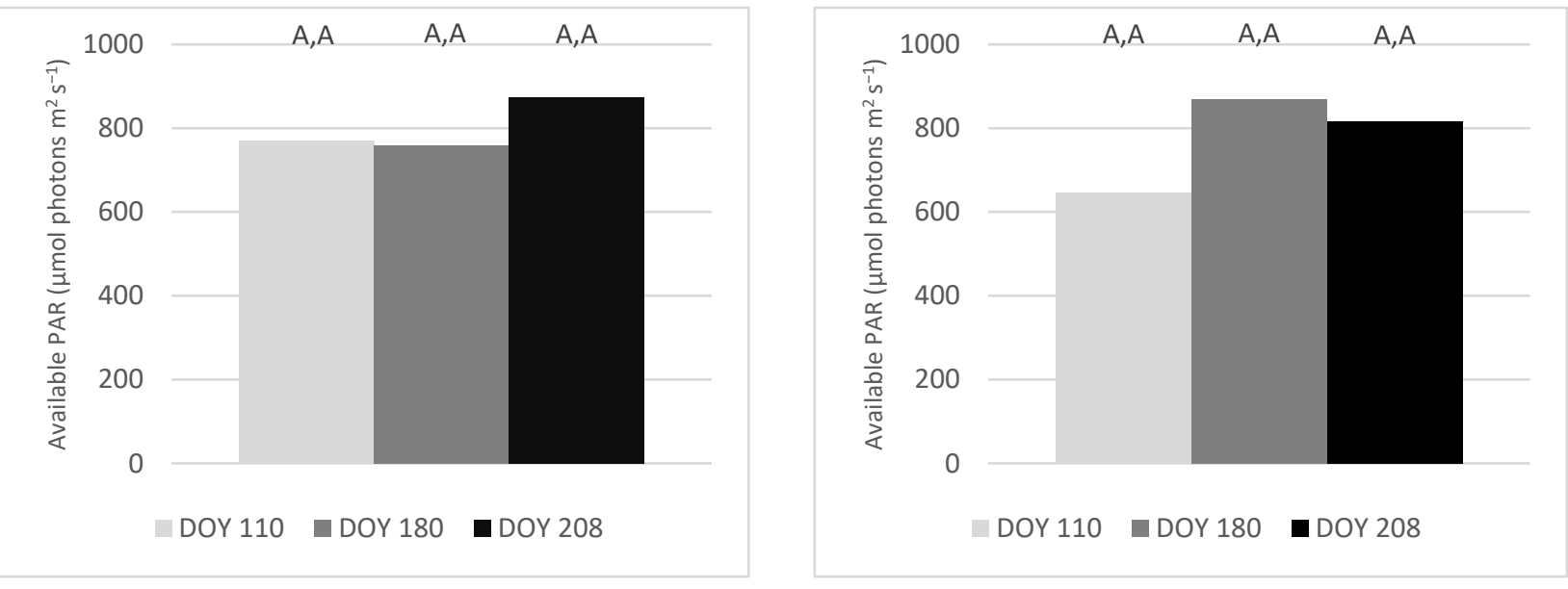

Layer B $(60-120 \mathrm{~cm})$
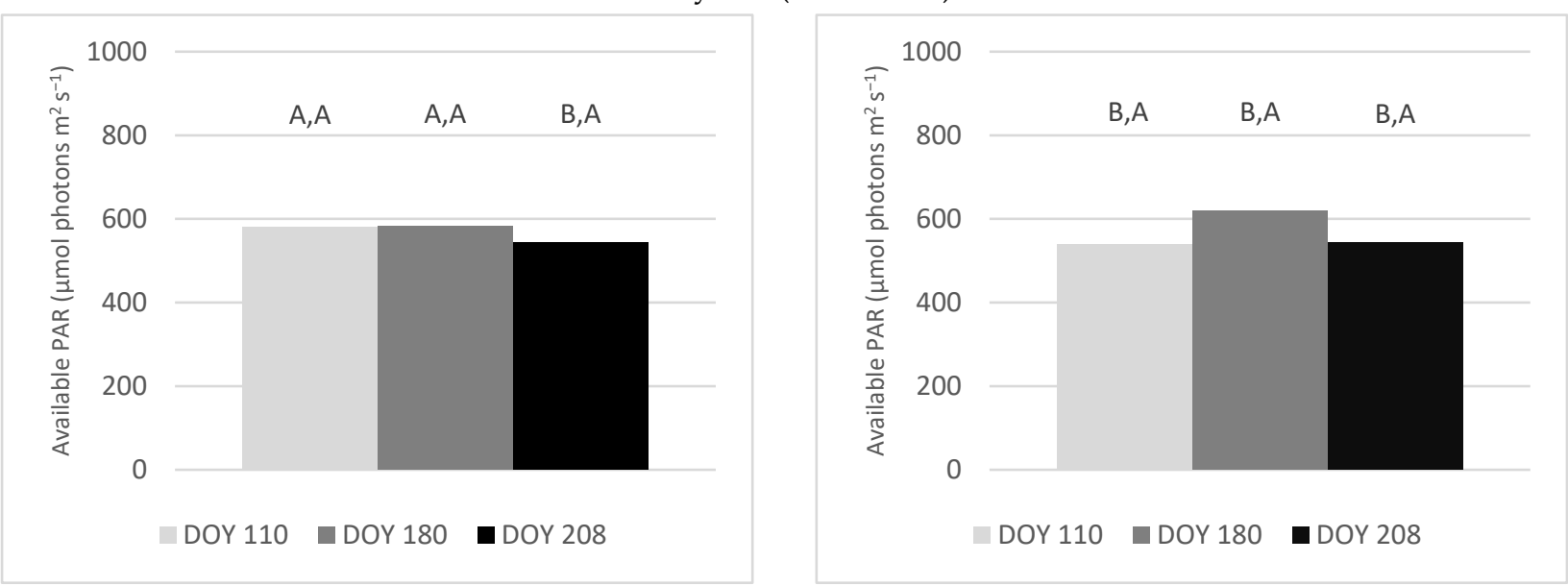

Layer C $(0-60 \mathrm{~cm})$
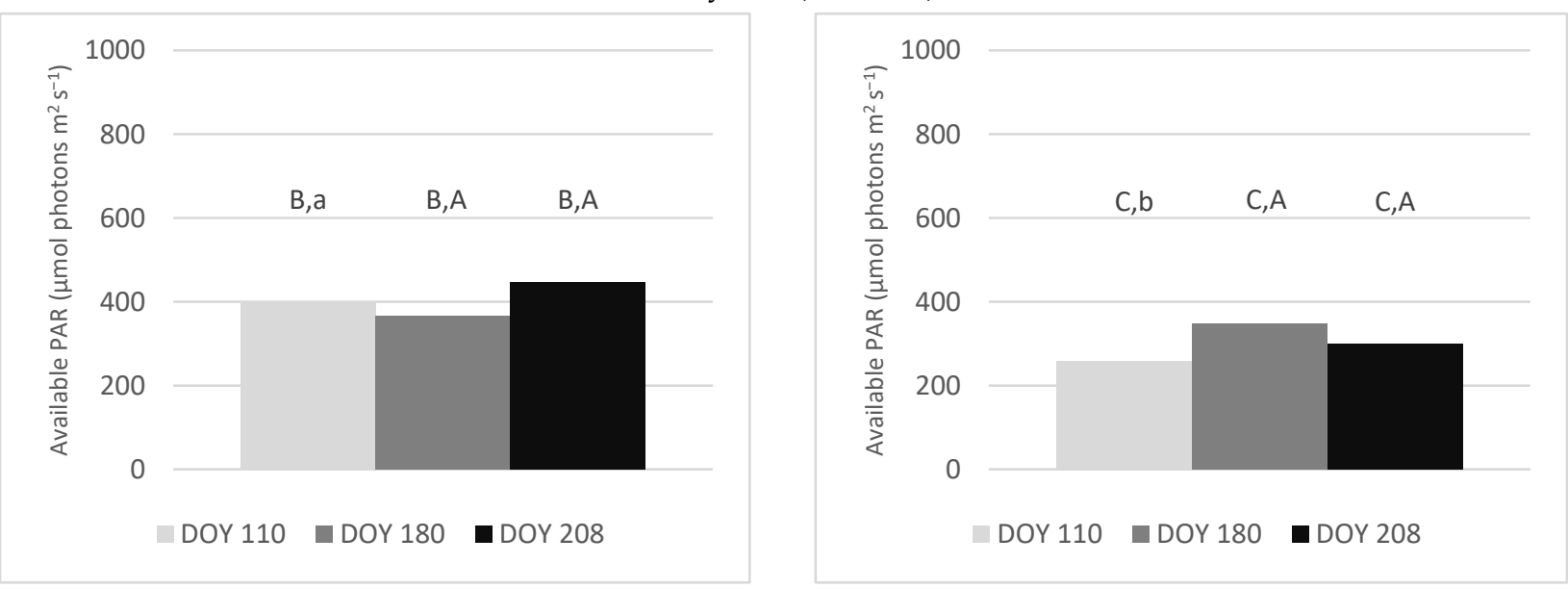

Figure 3. Available PAR ( $\mu \mathrm{mol}$ photons $\mathrm{m}^{2} \mathrm{~s}^{-1}$ ) in layers (A, B and C) of orchard with east-west orientation (north and south exposures) on three DOYs. The first letter denotes significant differences between layers for a given exposure and DOY ( $n=45 ; p=0.05 / 0.01$; SNK test); the second letter denotes significant differences between exposure for a given layer and DOY ( $n=90 ; p=0.05 / 0.01$; SNK test). Lower case letters denote statistical differences with $p=0.05$. Capital letters denote statistical differences with $p=0.01$. 


\subsection{Phenology}

The main phenological stages occurred on the same dates in both plots: full bloom on 68 DOY and ripening on 219 DOY, without differences in relation to row orientation.

\subsection{Agronomical Parameters}

Mean number of fruits per layer, FL (87.8), was $25 \%$ higher in the orchard with N-S orientation than in the one with E-W orientation (65.6) (Table 7). Mean FL (107.8) in layer B was $40 \%$ and $47 \%$ higher (significant) than in layers A (64.8) and C (57.5), respectively. It was $4 \%, 25 \%$ and $29 \%$ higher on the east side than on the west (85.8), north (67.3) and south (63.8) sides. Layer A produced 31\% more nuts per layer (76.6) in the plot with N-S orientation than in that with E-W orientation (52.9). The corresponding mean FLs for layers B and C were N-S (121.2), 22\% higher than E-W (94.4), and N-S (65.7), 25\% higher than E-W (49.3), respectively. With N-S row orientation, layer B (121.2) produced $37 \%$ and $46 \%$ more fruits per layer than layer A (76.6) and layer C (65.7), respectively. With E-W row orientation, mean FL of layer B (94.4) was $44 \%$ and $48 \%$ higher than that of layers A (52.9) and C (49.3). Mean FL of layer B with west exposure (127.9) was the highest, having $10 \%, 25 \%$ and $27 \%$ more fruits per layer than the east (114.5), south (95.7) and north (93.1) sides. Mean FL of layer C with east exposure (75.3) was the highest, having 25\%, 26\% and $43 \%$ more fruits per layer than the west (56.1), north (55.5) and south (43.1) sides, respectively. Finally, significant differences were found between mean FL in layers with different exposures. In east exposure, mean FL of layer B (114.5) was 30\% and $34 \%$ higher than those of layers A (79.7) and C (75.3); in west exposure, layer B (127.9) had 43\% and $56 \%$ more FL than layer A (73.5) and C (56.1). In north exposure, mean FL of layer B (93.1) was $40 \%$ and $43 \%$ higher than those of layers $C$ (55.5) and $A$ (53.3); in south exposure, layer B (95.7) had $45 \%$ and 55\% more FL than layers A (52.6) and C (43.1).

Table 7. Mean numbers of fruits per layer (FL). The first letters denote significant differences between layers for a given exposure; the second letters denote significant differences between exposures for a given layer (SNK test). Lower case letters denote statistical differences with $p=0.05$. Capital letters denote statistical differences with $p=0.01$.

\begin{tabular}{ccccccc}
\hline Orientation & \multicolumn{3}{c}{ North-South } & \multicolumn{3}{c}{ East-West } \\
\hline Layer/Exposure & East & West & Mean & North & South & Mean \\
\hline $120-180 \mathrm{~cm}$ & $79.7 \mathrm{~b}, \mathrm{~A}$ & $73.5 \mathrm{~B}, \mathrm{~A}$ & $76.6 \mathrm{~B}, \mathrm{~A}$ & $53.3 \mathrm{~B}, \mathrm{~A}$ & $52.6 \mathrm{~A}, \mathrm{~A}$ & $52.9 \mathrm{~B}, \mathrm{~B}$ \\
$60-120 \mathrm{~cm}$ & $114.5 \mathrm{a} \cdot \mathrm{ab}$ & $127.9 \mathrm{~A}, \mathrm{a}$ & $121.2 \mathrm{~A}, \mathrm{~A}$ & $93.1 \mathrm{~A}, \mathrm{~b}$ & $95.7 \mathrm{~A}, \mathrm{~b}$ & $94.4 \mathrm{~A}, \mathrm{~B}$ \\
$0-60 \mathrm{~cm}$ & $75.3 \mathrm{~b}, \mathrm{a}$ & $56.1 \mathrm{~B}, \mathrm{~b}$ & $65.7 \mathrm{~B}, \mathrm{~A}$ & $55.5 \mathrm{~B}, \mathrm{~b}$ & $43.1 \mathrm{~B}, \mathrm{~B}$ & $49.3 \mathrm{~B}, \mathrm{~B}$ \\
\hline Mean & $89.8 \mathrm{~A}$ & $85.8 \mathrm{AB}$ & $87.8 \mathrm{~A}$ & $67.3 \mathrm{AB}$ & $63.8 \mathrm{~B}$ & $65.6 \mathrm{~B}$ \\
\hline
\end{tabular}

Significant differences in mean percentage fruit set FS were found in relation to row orientation (Table 8). Mean FS for E-W orientation (50.4\%) was $34 \%$ higher than for N-S orientation (33.5\%). Significant differences were also found in relation to exposure: mean FS was $24 \%$ and $46 \%$ higher on the south side than on the west (39\%) and east $(27.7 \%)$ sides. Significant differences in fruit set were found in relation to orientation and layer. In layer B, mean FS (53.9\%) was $18.9 \%$ greater with E-W than with N-S orientation (35\%). In layer C, mean FS (55.0\%) was 57\% higher with E-W than with N-S orientation (23.9\%). Borderline significant variations in FS were found between layers in N-S orientation: mean FS in layer A $(41.2 \%)$ was $15 \%$ and $42 \%$ higher than in layers B (35.0\%) and C (23.9\%). Significant differences in FS were found between exposures in layer C: mean FS on the south side $(59.3 \%)$ was $14 \%, 54 \%$ and $65 \%$ higher than on the north $(50.8 \%)$, west $(27.0 \%)$ and east ( $20.9 \%)$ sides. Finally, on the east side, mean FS in layer A (33.6\%) was $15 \%$ and $38 \%$ greater than in layers B $(28.7 \%)$ and C (20.9\%), respectively; on the west side, layer A $(48.8 \%)$ showed $15 \%$ and $45 \%$ higher fruit set than layers B $(41.4 \%)$ and C $(27.0 \%)$, respectively. 
Table 8. Mean percentage fruit set (FS, \%). The first letters denote significant differences between layers for a given exposure; the second letters denote significant differences between exposures for a given layer (SNK test). Lower case letters denote statistical differences with $p=0.05$. Capital letters denote statistical differences with $p=0.01$.

\begin{tabular}{ccccccc}
\hline Orientation & \multicolumn{3}{c}{ North-South } & \multicolumn{3}{c}{ East-West } \\
\hline Exposure & East & West & Mean & North & South & Mean \\
\hline Layer A $(120-180 \mathrm{~cm})$ & $33.6 \mathrm{a}, \mathrm{A}$ & $48.8 \mathrm{a}, \mathrm{A}$ & $41.2 \mathrm{a}, \mathrm{A}$ & $46.7 \mathrm{~A}, \mathrm{~A}$ & $37.8 \mathrm{~A}, \mathrm{~A}$ & $42.2 \mathrm{~A}, \mathrm{~A}$ \\
Layer B $(60-120 \mathrm{~cm})$ & $28.7 \mathrm{ab}, \mathrm{A}$ & $41.3 \mathrm{ab}, \mathrm{A}$ & $35.0 \mathrm{ab}, \mathrm{b}$ & $51.7 \mathrm{~A}, \mathrm{~A}$ & $56.0 \mathrm{~A}, \mathrm{~A}$ & $53.9 \mathrm{~A}, \mathrm{a}$ \\
Layer C $(0-60 \mathrm{~cm})$ & $20.9 \mathrm{~b}, \mathrm{~B}$ & $27.0 \mathrm{~b}, \mathrm{ab}$ & $23.9 \mathrm{~b}, \mathrm{~B}$ & $50.8 \mathrm{~A}, \mathrm{ab}$ & $59.3 \mathrm{~A}, \mathrm{a}$ & $55.0 \mathrm{~A}, \mathrm{~A}$ \\
\hline Mean & $27.7 \mathrm{~B}$ & $39.0 \mathrm{AB}$ & $33.5 \mathrm{~B}$ & $49.7 \mathrm{~A}$ & $51.0 \mathrm{~A}$ & $50.4 \mathrm{~A}$ \\
\hline
\end{tabular}

Significant differences in mean fruit yield FY were found between layers (Table 9). Mean FY of layer B (469.2 g) was 39\% and 48\% higher than those of layers A (285.0 g) and C (244.7 g). Significant differences in FY were also found between layers in the two orientations. With N-S orientation, mean FY of layer B (491.3 g) was 34\% and $45 \%$ higher than those of layers A (324.3 g) and C (268.7 g). With E-W orientation, mean FY of layer B (447.0 g) was $45 \%$ and $51 \%$ higher than those of layers A $(245.7 \mathrm{~g})$ and C (220.7 g), respectively. Mean FY in the bottom layer on the east side $(298.7 \mathrm{~g})$ was $15 \%, 20 \%$ and $37 \%$ higher than on the north $(254.0 \mathrm{~g})$, west $(238.7 \mathrm{~g})$ and south $(187.3 \mathrm{~g})$ sides. Mean FY in the middle layer on the east side ( $476.0 \mathrm{~g}$ ) was $30 \%$ and $37 \%$ higher than in the top ( $333.3 \mathrm{~g}$ ) and bottom layers (298.7 g), respectively. Likewise for west exposure: mean FY in layer B $(506.7 \mathrm{~g})$ was $38 \%$ and $53 \%$ higher than in layers A ( $315.3 \mathrm{~g})$ and C ( $238.7 \mathrm{~g})$, respectively. In north exposure, FY in layer B (427.3 g) was $40 \%$ and $41 \%$ higher than in layers A (256.0 g) and C (254.0), respectively. Finally, for south exposure, mean FY in layer B (466.7 g) was $50 \%$ and $60 \%$ higher than in layers A (235.3 g) and C (187.3 g), respectively.

Table 9. Mean hulled fruit yield (FY, g). The first letters denote significant differences between layers for a given exposure; the second letters denote significant differences between exposures for a given layer (SNK test). Lower case letters denote statistical differences with $p=0.05$. Capital letters denote statistical differences with $p=0.01$.

\begin{tabular}{ccccccc}
\hline Orientation & \multicolumn{3}{c}{ North-South } & & \multicolumn{2}{c}{ East-West } \\
\hline Exposure & East & West & Mean & North & South & Mean \\
\hline Layer A $(120-180 \mathrm{~cm})$ & $333.3 \mathrm{ab}, \mathrm{A}$ & $315.3 \mathrm{~B}, \mathrm{~A}$ & $324.3 \mathrm{~B}, \mathrm{~A}$ & $256.0 \mathrm{~B}, \mathrm{~A}$ & $235.3 \mathrm{~B}, \mathrm{~A}$ & $245.7 \mathrm{~b}, \mathrm{~A}$ \\
Layer B $(60-120 \mathrm{~cm})$ & $476.0 \mathrm{a}, \mathrm{A}$ & $506.7 \mathrm{~A}, \mathrm{~A}$ & $491.3 \mathrm{~A}, \mathrm{~A}$ & $427.3 \mathrm{~A}, \mathrm{~A}$ & $466.7 \mathrm{~A}, \mathrm{~A}$ & $447.0 \mathrm{a}, \mathrm{A}$ \\
Layer C $(0-60 \mathrm{~cm})$ & $298.7 \mathrm{~B}, \mathrm{a}$ & $238.7 \mathrm{~B}, \mathrm{ab}$ & $268.7 \mathrm{~B}, \mathrm{~A}$ & $254.0 \mathrm{~B}, \mathrm{ab}$ & $187.3 \mathrm{~B}, \mathrm{~B}$ & $220.7 \mathrm{~b}, \mathrm{~A}$ \\
\hline Mean & $369.3 \mathrm{~A}$ & $353.6 \mathrm{~A}$ & $361.4 \mathrm{~A}$ & $312.4 \mathrm{~A}$ & $296.4 \mathrm{~A}$ & $304.4 \mathrm{~A}$ \\
\hline
\end{tabular}

No significant differences in mean weight of hulled almonds, AW, were found in relation to row orientation or exposure (Table 10).

Table 10. Mean weight of hulled almonds (AW, g). The first letters denote significant differences between layers for a given exposure; the second letters denote significant differences between exposures for a given layer (SNK test). Lower case letters denote statistical differences with $p=0.05$. Capital letters denote statistical differences with $p=0.01$.

\begin{tabular}{ccccccc}
\hline Orientation & \multicolumn{3}{c}{ North-South } & \multicolumn{3}{c}{ East-West } \\
\hline Exposure & East & West & Mean & North & South & Mean \\
\hline Layer A $(120-180 \mathrm{~cm})$ & $4.1 \mathrm{~A}, \mathrm{~A}$ & $4.2 \mathrm{~A}, \mathrm{~A}$ & $4.2 \mathrm{~A}, \mathrm{~A}$ & $4.9 \mathrm{~A}, \mathrm{~A}$ & $4.5 \mathrm{~A}, \mathrm{~A}$ & $4.7 \mathrm{~A}, \mathrm{~A}$ \\
Layer B $(60-120 \mathrm{~cm})$ & $4.1 \mathrm{~A}, \mathrm{~A}$ & $3.9 \mathrm{~A}, \mathrm{~A}$ & $4.1 \mathrm{~A}, \mathrm{~A}$ & $4.7 \mathrm{~A}, \mathrm{~A}$ & $5.9 \mathrm{~A}, \mathrm{~A}$ & $5.3 \mathrm{~A}, \mathrm{~A}$ \\
Layer C $(0-60 \mathrm{~cm})$ & $4.0 \mathrm{~A}, \mathrm{~A}$ & $4.3 \mathrm{~A}, \mathrm{~A}$ & $4.1 \mathrm{~A}, \mathrm{~A}$ & $4.6 \mathrm{~A}, \mathrm{~A}$ & $4.4 \mathrm{~A}, \mathrm{~A}$ & $4.5 \mathrm{~A}, \mathrm{~A}$ \\
\hline Mean & $4.1 \mathrm{~A}$ & $4.2 \mathrm{~A}$ & $4.1 \mathrm{~A}$ & $4.8 \mathrm{~A}$ & $5.0 \mathrm{~A}$ & $4.9 \mathrm{~A}$ \\
\hline
\end{tabular}




\subsection{Yield Quality Parameters}

Significant differences in mean hulled almond polar gauge, PG, were found in relation to row orientation (Table 11). Mean PG was higher in the plot with E-W (34.3 mm) than in the one with N-S $(33.5 \mathrm{~mm})$ orientation. Mean PG varied significantly in relation to exposure, being higher on the north and south $(34.4 \mathrm{~mm}$ and $34.3 \mathrm{~mm})$ than on the west $(33.9 \mathrm{~mm})$ and east $(33.2 \mathrm{~mm})$ sides of the hedges. Significant differences were also found in relation to layer: mean PG in layer A $(34.5 \mathrm{~mm})$ was higher than in layers B $(34.0 \mathrm{~mm})$ and C $(33.4 \mathrm{~mm})$. In layer A, mean PG was higher in E-W $(35.0 \mathrm{~mm})$ than in N-S oriented rows $(33.9 \mathrm{~mm})$, likewise in layer $B$, the corresponding mean values were $34.6 \mathrm{~mm}$ and $33.4 \mathrm{~mm}$, respectively. Mean PG was significantly different in the layers of orchards with E-W row orientation. In layer A, it was higher $(35.0 \mathrm{~mm})$ than in layers $B(34.6 \mathrm{~mm})$ and C $(33.4 \mathrm{~mm})$. Mean PG varied significantly in layer B in relation to exposure, being higher on the south and north ( $34.7 \mathrm{~mm}$ and $34.6 \mathrm{~mm}$, respectively) than on the west $(34.0 \mathrm{~mm})$ and east sides $(32.7 \mathrm{~mm})$. It also varied significantly in layers with north exposure: mean PG in layer A $(35.3 \mathrm{~mm})$ was slightly higher than in layers B $(34.6 \mathrm{~mm})$ and $C(33.1 \mathrm{~mm})$.

Table 11. Mean hulled almond polar gauge (PG, $\mathrm{mm}$ ). The first letters denote significant differences between layers for a given exposure; the second letters denote significant differences between exposures for a given layer (SNK test). Lower case letters denote statistical differences with $p=0.05$. Capital letters denote statistical differences with $p=0.01$.

\begin{tabular}{ccccccc}
\hline Orientation & \multicolumn{3}{c}{ North-South } & \multicolumn{3}{c}{ East-West } \\
\hline Exposure & East & West & Mean & North & South & Mean \\
\hline Layer A $(120-180 \mathrm{~cm})$ & $33.8 \mathrm{~A}, \mathrm{~A}$ & $34.1 \mathrm{~A}, \mathrm{~A}$ & $33.9 \mathrm{~A}, \mathrm{~B}$ & $35.3 \mathrm{a}, \mathrm{A}$ & $34.6 \mathrm{~A}, \mathrm{~A}$ & $35.0 \mathrm{~A}, \mathrm{~A}$ \\
Layer B $(60-120 \mathrm{~cm})$ & $32.7 \mathrm{~A}, \mathrm{~b}$ & $34.0 \mathrm{~A}, \mathrm{ab}$ & $33.4 \mathrm{~A}, \mathrm{~B}$ & $34.6 \mathrm{ab}, \mathrm{a}$ & $34.7 \mathrm{~A}, \mathrm{a}$ & $34.6 \mathrm{~A}, \mathrm{~A}$ \\
Layer C $(0-60 \mathrm{~cm})$ & $33.1 \mathrm{~A}, \mathrm{~A}$ & $33.6 \mathrm{~A}, \mathrm{~A}$ & $33.3 \mathrm{~A}, \mathrm{~A}$ & $33.1 \mathrm{~B}, \mathrm{~A}$ & $33.7 \mathrm{~A}, \mathrm{~A}$ & $33.4 \mathrm{~B}, \mathrm{~A}$ \\
\hline Mean & $33.2 \mathrm{~b}$ & $33.9 \mathrm{ab}$ & $33.5 \mathrm{~B}$ & $34.4 \mathrm{a}$ & $34.3 \mathrm{a}$ & $34.3 \mathrm{~A}$ \\
\hline
\end{tabular}

Significant differences in mean shelling percentage (SP) were found in relation to row orientation (Table 12), being higher for N-S (33.4\%) than for E-W orientation (31.1\%). Mean $\mathrm{SP}$ varied significantly in relation to exposure, being higher on the east and west $(33.2 \%$ and $33.6 \%$ ) than on the south and north sides (both $31.1 \%$ ). Mean SP also varied significantly in relation to layer, being higher in layer C (33.6\%) than in layers A $(32.0 \%)$ and B $(31.2 \%)$. Mean SP also varied significantly in a given layer in relation to row orientation. In layer A, it was higher with N-S rows (32.8\%) than with E-W rows (31.0\%); in layer B, it was higher with N-S (32.4\%) than with E-W (30.0\%) row orientation. The same situation was observed in layer C, where mean SP was higher with N-S rows (34.9\%) than with E-W rows (32.2\%). Significant differences in mean SP were found between layers for a given row orientation. With N-S orientation, mean SP was higher in layer C (34.9\%) than in layers A $(33.1 \%)$ and $B(32.1 \%)$. With E-W orientation, mean SP was again higher in layer C $(32.2 \%)$ than in layers A (31.0\%) and B (30.0\%). Significant differences in mean SP were also found between exposures in a given layer. In layer B, mean SP was higher on the east $(32.6 \%)$ than on the west $(32.1 \%)$, north $(30.3 \%)$ and south $(29.7 \%)$ sides. In layer C, mean SP was higher on the west $(35.4 \%)$ than on the east $(34.5 \%)$, south $(32.8 \%)$ and north $(31.7 \%)$ sides. Finally, significant differences in mean SP were found between layers in relation to exposure. On the west side of the hedges, mean SP was higher in layer C (35.4\%) than in layers A (33.1\%) and B (32.1\%). Likewise on the south side, mean SP was higher in layer C (32.8\%) than in layers A $(30.9 \%)$ and B $(29.7 \%)$. 
Table 12. Mean shelling percentage (SP, \%). The first letters denote significant differences between layers for a given exposure; the second letters denote significant differences between exposures for a given layer (SNK test). Lower case letters denote statistical differences with $p=0.05$. Capital letters denote statistical differences with $p=0.01$.

\begin{tabular}{ccccccc}
\hline Orientation & \multicolumn{3}{c}{ North-South } & \multicolumn{3}{c}{ East-West } \\
\hline Exposure & East & West & Mean & North & South & Mean \\
\hline Layer A $(120-180 \mathrm{~cm})$ & $32.6 \mathrm{~A}, \mathrm{~A}$ & $33.1 \mathrm{ab}, \mathrm{A}$ & $32.8 \mathrm{~b}, \mathrm{~A}$ & $31.2 \mathrm{~A}, \mathrm{~A}$ & $30.9 \mathrm{ab}, \mathrm{A}$ & $31.0 \mathrm{~B}, \mathrm{~B}$ \\
Layer B $(60-120 \mathrm{~cm})$ & $32.6 \mathrm{~A}, \mathrm{a}$ & $32.1 \mathrm{~b}, \mathrm{ab}$ & $32.4 \mathrm{~B}, \mathrm{~A}$ & $30.3 \mathrm{~A}, \mathrm{ab}$ & $29.7 \mathrm{~B}, \mathrm{~b}$ & $30.0 \mathrm{~B}, \mathrm{~B}$ \\
Layer C $(0-60 \mathrm{~cm})$ & $34.5 \mathrm{~A}, \mathrm{ab}$ & $35.4 \mathrm{a}, \mathrm{a}$ & $34.9 \mathrm{a}, \mathrm{A}$ & $31.7 \mathrm{~A}, \mathrm{~b}$ & $32.8 \mathrm{a}, \mathrm{ab}$ & $32.2 \mathrm{~A}, \mathrm{~B}$ \\
\hline Mean & $33.2 \mathrm{~A}$ & $33.6 \mathrm{~A}$ & $33.4 \mathrm{~A}$ & $31.1 \mathrm{~B}$ & $31.1 \mathrm{~B}$ & $31.1 \mathrm{~B}$ \\
\hline
\end{tabular}

Significant differences in mean percentage of hull-tight nuts (HT) were found in relation to row orientation (Table 13). Mean HT was $48 \%$ higher in the orchard with N-S (3.3\%) than in the one with E-W orientation (1.7\%). Significant differences in mean HT were found between exposures, with similar values on the west $(3.3 \%)$ and east $(3.2 \%)$ sides and values $42 \%$ and $55 \%$ higher on the north $(1.9 \%)$ and south $(1.5 \%)$ sides. Significant differences in mean HT were found in relation to orientation in different layers. In layer A, mean HT (3.0\%) was 53\% higher in the plot with N-S than in the one with E-W orientation $(1.4 \%)$. In layer B, mean HT (3.4\%) was 74\% higher in the plot with N-S than in the one with E-W orientation $(0.9 \%)$. Significant differences in mean HT were found in layer B in relation to exposure. Mean values were substantially equal on the west $(3.5 \%)$ and east sides $(3.3 \%)$ and were $63 \%$ and $83 \%$ higher than on the south $(1.3 \%)$ and north $(0.6 \%)$ sides, respectively. Finally, significant differences in mean HT were found on the north side in relation to layer: in layer C mean HT (3.7\%) was $77 \%$ and $84 \%$ higher than in layers A $(1.3 \%)$ and $\mathrm{B}(0.6 \%)$.

Table 13. Mean percentage of hull-tight nuts (HT, \%). The first letters denote significant differences between layers for a given exposure; the second letters denote significant differences between exposures for a given layer (SNK test). Lower case letters denote statistical differences with $p=0.05$. Capital letters denote statistical differences with $p=0.01$.

\begin{tabular}{ccccccc}
\hline Orientation & \multicolumn{3}{c}{ North-South } & \multicolumn{3}{c}{ East-West } \\
\hline Exposure & East & West & Mean & North & South & Mean \\
\hline Layer A $(120-180 \mathrm{~cm})$ & $3.2 \mathrm{~A}, \mathrm{~A}$ & $2.7 \mathrm{~A}, \mathrm{~A}$ & $3.0 \mathrm{~A}, \mathrm{~A}$ & $1.3 \mathrm{ab}, \mathrm{A}$ & $1.4 \mathrm{~A}, \mathrm{~A}$ & $1.4 \mathrm{~A}, \mathrm{~B}$ \\
Layer B $(60-120 \mathrm{~cm})$ & $3.3 \mathrm{~A}, \mathrm{~A}$ & $3.5 \mathrm{~A}, \mathrm{~A}$ & $3.4 \mathrm{~A}, \mathrm{~A}$ & $0.6 \mathrm{~b}, \mathrm{~B}$ & $1.3 \mathrm{~A}, \mathrm{~B}$ & $0.9 \mathrm{~A}, \mathrm{~B}$ \\
Layer C $(0-60 \mathrm{~cm})$ & $3.3 \mathrm{~A}, \mathrm{~A}$ & $3.7 \mathrm{~A}, \mathrm{~A}$ & $3.5 \mathrm{~A}, \mathrm{~A}$ & $3.7 \mathrm{a}, \mathrm{A}$ & $1.7 \mathrm{~A}, \mathrm{~A}$ & $2.7 \mathrm{~A}, \mathrm{~A}$ \\
\hline Mean & $3.2 \mathrm{a}$ & $3.3 \mathrm{a}$ & $3.3 \mathrm{~A}$ & $1.9 \mathrm{ab}$ & $1.5 \mathrm{~b}$ & $1.7 \mathrm{~B}$ \\
\hline
\end{tabular}

No significant differences in mean percentage of double seeds, (DS), were found in relation to orientation or exposure (Table 14).

Table 14. Mean percentage of double seeds (DS, \%). The first letters denote significant differences between layers for a given exposure; the second letters denote significant differences between exposures for a given layer (SNK test). Lower case letters denote statistical differences with $p=0.05$. Capital letters denote statistical differences with $p=0.01$.

\begin{tabular}{ccccccc}
\hline Orientation & \multicolumn{3}{c}{ North-South } & \multicolumn{3}{c}{ East-West } \\
\hline Exposure & East & West & Mean & North & South & Mean \\
\hline Layer A $(120-180 \mathrm{~cm})$ & $7.1 \mathrm{~A}, \mathrm{~A}$ & $7.6 \mathrm{~A}, \mathrm{~A}$ & $7.4 \mathrm{~A}, \mathrm{~A}$ & $10.0 \mathrm{~A}, \mathrm{~A}$ & $9.5 \mathrm{~A}, \mathrm{~A}$ & $9.7 \mathrm{~A}, \mathrm{~A}$ \\
Layer B $(60-120 \mathrm{~cm})$ & $7.9 \mathrm{~A}, \mathrm{~A}$ & $9.5 \mathrm{~A}, \mathrm{~A}$ & $8.7 \mathrm{~A}, \mathrm{~A}$ & $6.1 \mathrm{~A}, \mathrm{~A}$ & $6.8 \mathrm{~A}, \mathrm{~A}$ & $6.5 \mathrm{~A}, \mathrm{~A}$ \\
Layer C $(0-60 \mathrm{~cm})$ & $9.9 \mathrm{~A}, \mathrm{~A}$ & $9.5 \mathrm{~A}, \mathrm{~A}$ & $9.8 \mathrm{~A}, \mathrm{~A}$ & $6.6 \mathrm{~A}, \mathrm{~A}$ & $9.2 \mathrm{~A}, \mathrm{~A}$ & $7.9 \mathrm{~A}, \mathrm{~A}$ \\
\hline Mean & $8.2 \mathrm{~A}$ & $9.0 \mathrm{~A}$ & $8.6 \mathrm{~A}$ & $7.6 \mathrm{~A}$ & $8.5 \mathrm{~A}$ & $8.1 \mathrm{~A}$ \\
\hline
\end{tabular}




\section{Discussion and Conclusions}

Due to a lack of studies on the effects of row orientation in SHD almond orchards, we compared our results with those of studies on vineyards, SHD olive orchards and other orchards of deciduous species.

The total number of buds showed significant differences. Orchards with N-S orientation had more buds than those with E-W orientation in all layers and exposures (Table 1). A linear increase was observed from the south side of E-W orchards to the east side of N-S orchards, and this trend was also found with slight differences between exposures in every layer. No differences were found between layers, except in the case of south exposure where the bottom layer had the fewest buds. On the contrary, in E-W oriented olive groves, top canopy layers seemed to have a greater total number of buds $[24,38,39]$.

Bud differentiation was barely influenced by row orientation (Tables 2 and 3): N-S orientation determined flower bud numbers three times greater than did E-W orientation; in particular, flower bud number on the east side was four times greater than on the south side. The bottom layer had the highest mean flower bud number for all orientations and exposures, except in the case of southern exposure, which showed the lowest bud number. Consequently, wood buds were more numerous in E-W than in N-S oriented rows.

Nevertheless, in N-S row orientation the number of wood and flower buds on the east and west sides was balanced, while in E-W row orientation, wood buds were $80 \%$ of total buds on both sides (Figure 1). This is probably due to photo-damage caused by excessive interception of radiation on the southern side and lack of intercepted light on the northern side. Over-excitation of chlorophyll promotes production of reactive oxygen species (ROS), increasing the risk of photo-inhibition (i.e., photo-damage) [40]. Moreover, fewer inflorescences have been reported in canopy areas that receive low PAR [41]. In fact, in almond orchards, exposure of canopy and fruit to radiation is another aspect of the radiation environment that is modified by hedgerow orientation. Radiation can severely damage plants via direct and indirect effects on cell constitution, causing a decrease in chlorophyll concentration and photosynthesis rate [32,42,43]. Net photosynthesis increases with light up to saturation, beyond which additional photosynthetic photon flux density (PPFD) does not improve carboxylation, rendering excessive about half the available light. For taller fruit tree species, the saturation point is variable [40]. For almond trees, the saturation point varies with cultivar, averaging $1263 \mu \mathrm{mol} \mathrm{m}^{-2} \mathrm{~s}^{-1}$ [44].

For N-S hedgerows that receive equal daily irradiance on both sides according to season and latitude, transmission between sides is correspondingly equal. For E-W hedgerows, by contrast, the annual pattern of incidence of the solar beam differs sharply between sides in relation to season and latitude. All beam irradiance falls on the S side from the autumn to the spring equinox, while the $\mathrm{N}$ side only receives beam irradiance for short periods in summer. During the rest of the year, the $\mathrm{N}$ side relies on diffuse and reflected radiation in the alleys and that transmitted through the hedgerow from the $S$ side [32].

In olive and grape orchards, floral induction was not related to row orientation or to canopy layer $[24,25]$. In olive trees, the flowering stimulus seems to translocate from more illuminated to poorly illuminated canopy positions [45,46]. Moreover, different light saturation points lead to different responses of fruit tree species [40].

In apple orchards, row orientation combined with tree height and latitude affected light interception, distribution and fruit quality in model apple hedgerow canopies [47]. In adult Anjou pear trees conducted in hedgerow, Khemira et al. [48] reported a positive effect of row orientation on canopy exposure, flowering index and fruit set. Day et al. [49] studied different orchard-system configurations, combining rootstocks, varieties, training systems and row orientation; all had a significant effect on the profitability of peaches and nectarines.

LAI values are strictly related to sampling DOY. Leaf development begins in March, reaching maximum values in early summer (DOY 180), and then gradually decreases until late September (Table 4). This pattern was confirmed by Sakar et al. [37] in almond. 
LAI values clearly increased from the top to the bottom of the canopy, but no effect of exposures and orientations was observed (Table 5). In fact, the small effect of row orientation decreased with increasing latitude [50]. If at $55^{\circ} \mathrm{N}, \mathrm{LAI}$ is highest with $\mathrm{N}-\mathrm{S}$ orientation in the summer months and with $\mathrm{E}-\mathrm{W}$ orientations for the rest of the year, at $41^{\circ} \mathrm{N}$ it is very similar.

A PAR gradient was found from the top to the bottom layer (Table 6), due to less light intercepted in the lowest part of the canopy. For the lowest layer, PAR was least on the east and south sides, and highest on the west and north sides. In the middle layer, the situation was quite similar: east showed lower PAR than west exposure, while north and south received about the same PAR. These results may be related to a thicker canopy, normal on the south side. An unusual finding was that the same was found for eastern exposure. This could be explained by the proverb "The early bird catches the worm": the net assimilation rate in the morning hours is higher than in the afternoon due to the better physiological condition of the tree. With west exposure, the light is captured in the afternoon, when the physiological condition of trees suffers from closed stomata. Higher afternoon temperature could also lead to a reduction in photosystem efficiency [20]. In the top layer the situation is different, with the highest PAR on the west side, decreasing towards north.

Flowering and ripening times were not influenced by row orientation. No data on this aspect is available in the literature.

Fruit number per layer fluctuated widely with orientation, exposure and layer (Table 7).

A greater number of fruits was recorded in N-S oriented rows, in line with the greater number of flower buds. These differences were also found between exposures, where east proved to be the most and southern exposure the least productive, in line with flower bud distribution. This evidence is at variance with Trentacoste et al. [22] who did not find any significant differences between exposures in orchards with rows oriented N-S and E-W.

We found the highest number of fruits in mid position, for both orientations, while in olive, fruit number per layer increased linearly from bottom to top, as did inflorescences [24]. In our case, this is probably due to incomplete growth and development at the top of the tree canopies.

The highest mean values of fruit set were found in E-W orientation ( $\mathrm{N}$ and $\mathrm{S}$ exposures), while E exposure had the lowest (Table 8). Fruit set values showed an opposite trend with respect to fruit number per layer and flower bud number. This is a consequence of total bud number and bud induction, as reported before. In SHD olive and grape, fruit set was not responsive to irradiance, presumably due to different light saturation points $[24,25,40]$. In line with Trentacoste et al. [22,24] in olive, our study confirmed that in almond, row orientation and exposure did not affect hulled fruit yield from the middle and top layers of the canopy (Table 9). In olive, Tous et al. [51] reported greater yield with N-S orientation as in grape [25,52,53], whereas Gòmez-del-Campo et al. [54] observed higher yield with E-W orientation. These contradictory results could be due to different experimental and climatic conditions [32]. The middle layer had the highest mean hulled fruit yield irrespective of orientation and exposure. However, with $S$ exposure, the hulled fruit yield of the lower layer was significantly less than that of other exposures, related to the lowest number of fruits per layer (Table 7).

No significant variations in hulled fruit average weight were found in relation to orientation, exposure or layer (Table 10). In the case of hard-shelled almonds, Dicenta et al. [55] found high heritability of this trait, but observed a slight effect of the year, due to the known influence of productivity on fruit size [56]. These results were in contrast with Trentacoste et al. [22], who found that olive weight was responsive to irradiance, and with Hunter et al. [25], who found that berry mass was higher in the case of E-W orientation, presumably due to the different organ types: seed (almond) vs. stone fruit (olive) vs. berry fruit (grape).

E-W row orientation showed mean hulled fruit polar gauge consistently greater than did N-S orientation. There was a linear increase in gauge from the lower to the upper layer, mainly for E-W row orientation (Table 11). Trentacoste et al. [24] showed weakly significant 
increases in olive gauge with illumination and Hunter et al. [25] observed greater berry volumes with E-W orientation. Although our work seems to be in line with grape, these parameters cannot be compared because the organs analyzed were different.

Shelling is a very important parameter for the agronomical characterization and value of almond cultivars. Mean shelling (32.3\%) was slightly lower than values reported in the literature for Guara/Tuono [57,58]. Although shelling was greater for N-S $(33.4 \%)$ than E-W orientation (31.1\%) and in lower layers (33.6\%) (Table 12), these differences do not have any practical impact from an agronomical point of view. No comparison could be made with other similar studies.

N-S orientation was associated with an almost double hull tight nut percentage $(3.3 \%)$ than was E-W orientation (1.7\%) (Table 13). The middle layer showed the highest percentage in N-S oriented trees (3.4\%). In fact, Kester et al. [59] observed a considerable influence of the environment on expression of this trait. No studies on this parameter are available in the literature for $\mathrm{cv}$ Guara/Tuono, probably due to the marginal impact of this parameter on total yield. In our research, the average percentage was $2.5 \%$, while for other cultivars a value of $1 \%$ is reported [60].

The percentage of double seeds is important for almonds because it determines the use of the crop (sugared almonds versus pastry-making). The mean value recorded for this study was $8.4 \%$, lower than the standard mean values of almond cultivars [58,59]. This parameter was not affected by orientation or layer (Table 14). Other studies have reported that this is a quantitative trait with complex inheritance and difficult-to-estimate heritability $[55,59,61,62]$.

Pearson correlation coefficients were also evaluated between all the parameters (Table S1). Bud parameters were closely correlated with each other, showing a strong correlation between TB and FB. The same goes for the relation between FN and FB. Very high correlations were found between FY and FL and between FY and AW. The first relation shows that the greater the number of fruits, the heavier the yield of the specific layer. Finally, LAI showed a close negative correlation with PAR.

Super-high density is the latest innovation in almond orchards. This new cropping system needs to be studied to observe how it responds to different climates, soils, latitudes and irradiance levels, so as to help growers manage their almond orchards more efficiently.

In this context, our study is the first, and shows that although no differences in LAI were recorded between orientations, higher values for most biological and agronomical parameters were recorded with N-S orientation. The number of wood buds, fruit set and hulled fruit polar gauge were the only parameters that were higher with E-W orientation. Hulled fruit yield, total and average weight and double seed percentage were not influenced by row orientation.

Felipe et al. [63] surmised the effects of row orientation on the main biological and yield parameters of almond trees. The present study is the first to confirm these effects, showing the key role of row orientation in the sustainable management of SHD almond orchards. More detailed research on this topic is needed.

Supplementary Materials: The following are available online at https:/ /www.mdpi.com/2073-439 5/11/2/251/s1. Table S1: Pearson's correlation coefficients between all parameters.

Author Contributions: Conceptualization, S.C. and F.M.; methodology, S.C.; software, G.A.V.; validation, S.C., and I.I.-C.; data curation, F.M.; writing-original draft preparation, F.M.; writing-review and editing, S.C., G.A.V. and I.I.-C.; supervision, S.C. All authors have read and agreed to the published version of the manuscript.

Funding: This research received no external funding.

Acknowledgments: We would like to thank the "Azienda Agricola Alfonso Di Pietro", Andria, for access to their orchards and logistic support.

Conflicts of Interest: The authors declare that they have no conflicts of interest. 


\section{References}

1. Food and Agriculture Organization of the United Nations-FAOSTAT. Available online: http://www.fao.org/faostat/en/\#home (accessed on 30 December 2020).

2. Global Almond Market 2019-After Five Years of Robust Growth of In-Shell Nut Imports, India Emerges at the Most Promising Market. Available online: https:/ / www.globaltrademag.com/global-almond-market-2019-after-five-years-of-robust-growthof-in-shell-nut-imports-india-emerges-as-the-most-promising-market/ (accessed on 30 December 2020).

3. Iglesias, I.; Foles, P.; Oliveira, C. El cultivo del almendro en España y Portugal: Situación, innovación tecnológica, costes, rentabilidad y perspectivas. Revista de Fruticultura 2021, 80.

4. Fadón, E.; Herrera, S.; Guerrero, B.I.; Guerra, M.E.; Rodrigo, J. Chilling and Heat Requirements of Temperate Stone Fruit Trees (Prunus spp.). Agronomy 2020, 10, 409. [CrossRef]

5. Iglesias, I. Costes de producción, sistemas de formación y mecanización en frutales, con especial referencia al melocotonero. Rev. Fruticult. 2019, 69, 50-59.

6. Iglesias, I. El almendro en España: Situación, innovación tecnológica, costes y retos para una producción sostenible. Horticulture 2020, 350, 14-28.

7. Expósito, A.; Berbel, J. The Economics of Irrigation in Almond Orchards. Application to Southern Spain. Agronomy 2020, 10, 796. [CrossRef]

8. Camposeo, S.; Palasciano, M.; Vivaldi, G.A.; Godini, A. Effect of increasing climatic water deficit on some leaf and stomatal parameters of wild and cultivated almonds under Mediterranean conditions. Sci. Hortic. 2011, 127, 234-241. [CrossRef]

9. Iglesias, I. Sistemas de plantación 2D: Una novedad en almendro, una realidad en frutales. Hacia una alta eficiencia. Rev. Fruticult. 2019, 67, 22-44.

10. Caruso, T.; Campisi, G.; Marra, F.P.; Camposeo, S.; Vivaldi, G.A.; Proietti, P.; Nasini, L. Growth and yields of the cultivar Arbequina in high density planting systems in three different olive growing areas in Italy. Acta Hortic. 2014, 1057, 341-348. [CrossRef]

11. Camposeo, S.; Vivaldi, G.A.; Gattullo, C.E. Ripening indices and harvesting times of different olive cultivars for continuous harvest. Sci. Hortic. 2013, 151, 1-10. [CrossRef]

12. Vivaldi, G.A.; Strippoli, G.; Pascuzzi, S.; Stellacci, A.M.; Camposeo, S. Olive genotypes cultivated in an adult high-density orchard respond differently to canopy restraining by mechanical and manual pruning. Sci. Hortic. 2015, 192, 391-399. [CrossRef]

13. Camposeo, S.; Vivaldi, G.A. Yield, harvesting efficiency and oil chemical quality of cultivars Arbequina and Arbosana harvested by straddle machine in two Apulian growing areas. Acta Hortic. 2018, 1199, 397-402. [CrossRef]

14. Connor, D.J.; Goméz-del-Campo, M.; Rousseaux, M.C.; Searles, P.S. Structure, management and productivity of hedgerow olive orchards: A review. Sci. Hortic. 2014, 169, 71-93. [CrossRef]

15. Pellegrini, G.; La Sala, P.; Camposeo, S.; Contò, F. Economic sustainability of the oil high and super-high density cropping systems in Italy. Glob. Bus. Econ. Rev. 2017, 19, 553-569. [CrossRef]

16. Russo, G.; Vivaldi, G.A.; De Gennaro, B.; Camposeo, S. Environmental sustainability of different soil management techniques in a high-density olive orchard. J. Clean. Prod. 2015, 16, 498-508. [CrossRef]

17. Pellegrini, G.; Ingrao, C.; Camposeo, S.; Tricase, C.; Contò, F.; Huisingh, D. Application of Water Footprint to olive growing systems in the Apulia region: A comparative assessment. J. Clean. Prod. 2016, 112, 2407-2418. [CrossRef]

18. Roca, J.M.; Gòmez, J.M.; Lòpez, M. El almendro en seto SHD. La recolecciòn con màquinas cabalgantes. Olint $2014,25,35-45$.

19. Rodas, A. SHD en el mundo. Paìses con presencia de plantaciones en sistema superintensivo de almendro. Olint 2015, 28, 24-25.

20. Casanova-Gascòn, J.; Figueras-Panillo, M.; Iglesias-Castellarnau, J.; Martin-Ramos, P. Comparison of SHD and Open-Center Training Systems in Almond Tree Orchards cv. "Soleta". Agronomy 2019, 9, 874. [CrossRef]

21. Iglesias, I.; Torrents, J. Diseño de nuevas plantaciones adaptadas a la mecanización en frutales. Horticulture 2020, 346, 60-67.

22. Trentacoste, E.R.; Connor, D.J.; Goméz-del-Campo, M. Effect of olive hedgerow orientation on vegetative growth, fruit characteristics and productivity. Sci. Hortic. 2015, 192, 60-69. [CrossRef]

23. Trentacoste, E.R.; Connor, D.J.; Goméz-del-Campo, M. Effect of row spacing on vegetative structure, fruit characteristics and oil productivity of N-S and E-W oriented olive hedgerows. Sci. Hortic. 2015, 193, 240-248. [CrossRef]

24. Trentacoste, E.R.; Moreno-Alìas, I.; Goméz-del-Campo, M.; Beyà-Marshall, V.; Rapoport, H.F. Olive floral development in different hedgerow positions and orientations as affected by irradiance. Sci. Hortic. 2017, 225, 226-234. [CrossRef]

25. Hunter, J.J.; Volschenk, C.G.; Booyse, M. Vineyard row orientation and grape ripeness level effects on vegetative and reproductive growth cheracteristics of Vitis vinifera L. cv. Shiraz/101-14 Mgt. Eur. J. Agron. 2017, 84, 47-57. [CrossRef]

26. Giacosa, S.; Marengo, F.; Guidoni, S.; Rolle, L.; Hunter, J.J. Anthocyanin Yield and skin softening during maceration, as affected by vineyard row orientation and grape ripeness of Vitis vinifera. Food Chem. 2015, 174, 8-15. [CrossRef] [PubMed]

27. Dalla Marta, A.; Di Stefano, V.; Cerovic, Z.G.; Agati, G.; Orlandini, S. Solar radiation affects grapevine susceptibility to Plasmopara viticola. Sci. Agric. 2008, 65, 65-70. [CrossRef]

28. Thomas, C.S.; Marois, J.J.; English, J.T. The effects of wind speed, temperature, and relative humidity on development of aerial mycelium and conidia of Botrytis cinerea on grape. Phytopathology 1988, 78, 260-265. [CrossRef]

29. Grifoni, D.; Carreras, G.; Zipoli, G.; Sabatini, F.; Dalla Marta, A.; Orlandini, S. Row orientation effect on UV-B, UV-A and PAR solar irradiation components in vineyards at Tuscany, Italy. Int. J. Biometeorol. 2008, 52, 755-763. [CrossRef] 
30. Hunter, J.J.; Volschenk, C.G.; Zorer, R. Vineyard row orientation of Vitis vinifera L. cv. Shiraz/101-14 Mgt: Climatic profiles and vine physiological status. Agric. For. Meteorol. 2016, 228-229, 104-119. [CrossRef]

31. Cherbiy-Hoffmann, S.U.; Hall, A.J.; Rousseaux, M.C. Fruit, yield, and vegetative growth response to photosynthetically active radiation during oil synthesis in olive trees. Sci. Hortic. 2013, 150, 110-116. [CrossRef]

32. Trentacoste, E.R.; Connor, D.J.; Goméz-del-Campo, M. Row orientation: Applications to productivity and design of hedgerows in horticultural and olive orchards. Sci. Hortic. 2015, 187, 15-29. [CrossRef]

33. Connor, D.J.; Goméz-del-Campo, M.; Trentacoste, E.R. Relationships between olive yield components and simulated irradiance within hedgerows of various row orientations and spacings. Sci. Hortic. 2016, 198, 12-20. [CrossRef]

34. Dias, A.B.; Caeiro, L.; Félix, G.; Falcao, J.M. Evaluation of biometric parameters of 'Belona', 'Guara' and 'Lauranne' cultivars in a superhigh density orchard. Acta Hortic. 2018, 1219. [CrossRef]

35. Dicenta, F.; Sànchez-Pèrez, R.; Rubio, M.; Egea, J.; Battle, I.; Miarnau, X.; Palasciano, M.; Lipari, E.; Confolent, C.; Martìnez-Gòmez, P.; et al. The origin of the self-compatible almond 'Guara'. Sci. Hortic. 2015, 197, 1-4. [CrossRef]

36. Felipe, A.J. On the origin of "Guara" almond. FAO-CIHEAM Nucis-Newsl. 2017, 17, 16-18.

37. Sakar, E.H.; El Yamani, M.; Boussakouran, A.; Rharrabti, Y. Codification and description of almond (Prunus dulcis) vegetative and reproductive phenology according to the extended BBCH scale. Sci. Hortic. 2019, 247, 224-234. [CrossRef]

38. Acebedo, M.M.; Cañete, M.L.; Cuevas, J. Processes affecting fruit distribution and its quality in the canopy of olive trees. Adv. Hort. Sci. 2000, 14, 169-175.

39. Pastor, M.; García-Vila, M.; Soriana, M.A.; Vega, V.; Fereres, E. Productivity of olive orchards in response to tree density. J. Hortic. Sci. Biotechnol. 2007, 82, 555-562. [CrossRef]

40. Losciale, P.; Pierpaoli, E.; Corelli Grappaldelli, L. Gestione dell'energia radiante nelle piante da frutto: Utilizzazione, fotoprotezione e foto-danno. Quali implicazioni per la produttività? Italus Hortus 2009, 16, 1-22.

41. Gregoriou, K.; Pontikis, K.; Vemmos, S. Effects of reduced irradiance on leaf morphology, photosynthetic capacity, and fruit yield in Olive (Olea europaea L.). Photosynthetica 2007, 45, 172-181. [CrossRef]

42. Ranjbarfordoei, A.; van Damme, P.; Samson, R. Elevated ultraviolet-B radiation influences photosysnthetic pigments and soluble carbohydrates of sweet almond (Prunus dulcis (Miller) D. Webb). Electr. J. Environ. Agric. Food Chem. 2009, 8, $1078-1084$.

43. Ranjbarfordoei, A.; Samson, R.; Van Damme, P. Photosynthesis performance in sweet almond [Prunus dulcis (Mill) D. Webb] exposed to supplemental UV-B radiation. Photosynthetica 2011, 49, 107-111. [CrossRef]

44. De Herralde, F.; Biel, C.; Savé, R. Leaf photosynthesis in eight almond tree cultivars. Biol. Plant. 2003, 46, 557-561. [CrossRef]

45. Proietti, P.; Tombesi, A. Translocation of assimilates and -sink influences on productive characteristics of the olive tree. Adv. Hortic. Sci. 1996, 10, 11-14.

46. Fabbri, A.; Benelli, C. Flower bud induction and differentiation in olive. J. Hortic. Sci. Biotechnol. 2000, 75, 131-141. [CrossRef]

47. Palmer, J.W. The effects of row orientation, tree height, time of year and latitude on light interception and distribution in model apple hedgerow canopies. J. Hortic. Sci. 1989, 64, 137-145. [CrossRef]

48. Khemira, H.; Lombard, P.B.; Sugar, D.; Azarenko, A.N. Hedgerow Orientation Affects Canopy Exposure, Flowering, and Fruiting of 'Anjou' Pear Trees. HortScience 1993, 28, 984-987. [CrossRef]

49. Day, K.; DeJong, T.; Johnson, R. Orchard-system configurations increase efficiency, improve profits in peaches and nectarines. Calif. Agric. 2005, 59, 75-79. [CrossRef]

50. Mutsaers, H. The effect of row orientation, date and latitude on light absorption by row crops. J. Agric. Sci. 1980, 95, 381-386. [CrossRef]

51. Tous, J.; Romero, A.; Hermoso, J.F.; Msallem, M.; Larbi, A. Olive orchard design and mechanization: Present and future. Acta Hortic. 2014, 1057, 231-246. [CrossRef]

52. Intrieri, C.; Silvestroni, O.; Rebucci, B.; Poni, S.; Filippetti, I. The effects of row orientation on growth, yield, quality and dry matter partitioning in Chardonnay vines trained to simple curtain and spur-pruned cordon. In Proceedings of the 4th International Symposium on Cool Climate Viticulture and Enology, Rochester, NY, USA, 16-20 July 1996; pp. 10-15.

53. Trought, M.C.T.; Naylor, A.P.; Frampton, C. Effect of row orientation, trellis type, shoot and bunch position on the variability of Sauvignon Blanc (Vitis vinifera L.) juice composition. Austr. J. Grape Wine Res. 2017, 23, 240-250. [CrossRef]

54. Gómez-del-Campo, M.; Centeno, A.; Connor, D.J. Yield determination in olive hedgerow orchards. I. Yield and profiles of yield components in north-south and east-west oriented hedgerows. Crop Pasture Sci. 2009, 60, 434-442. [CrossRef]

55. Dicenta, F.; Garcìa, J.E.; Carbonell, E.A. Heritability of fruit characters in almond. Sci. Hortic. 1993, 68, 121-126. [CrossRef]

56. Hill, S.J.; Stephenson, D.W.; Taylor, B.K. Almond yield in relation to tree size. Sci. Hortic. 1987, 33, 97-111. [CrossRef]

57. Sottile, F.; Palasciano, M.; Godini, A. Le liste varietali 2009 per il mandorlo. Inf. Agr. 2009, 23, 54-55.

58. Palasciano, M. Tutte le varietà consigliate per il mandorlo 2015. Inf. Agr. 2015, 20, 47-49.

59. Kester, D.E.; Hansche, P.E.; Beres, W.; Asay, R.N. Variance components and heritability of nut and kernel traits in almond. J. Am. Soc. Hortic. Sci. 1977, 102, 264-266.

60. Sànchez-Pérez, R.; Ortega, E.; Duval, H.; Martìnez-Gòmez, P.; Dicenta, F. Inheritance and relationships of important agronomic traits in almond. Euphytica 2007, 155, 381-391. [CrossRef]

61. Martínez-García, P.J.; Ortega, E.; Cremades, T.; Dicenta, F. Heritability and phenotypic variation of double seeds in almond (Prunus dulcis). Euphytica 2014, 198, 91-99. [CrossRef] 
62. Arteaga, N.; Socias i Company R. Heritability of fruit and kernel traits in almond. Acta Hort. 2001, 591, 269-274. [CrossRef]

63. Felipe, A.J.; Rius, X.; Rubio-Cabetas, M.J. El Cultivo del Almendro; Araconsa: Zaragoza, Spain, 2017; p. 86. ISBN 978-0-646-97816-1. 